\title{
Quantifying the integration of renewable energy sources in West Africa's interconnected electricity network
}

\author{
Omotola Adeoye $\mathrm{a}^{\mathrm{*}}$, Catalina Spataru ${ }^{\mathrm{a}}$. \\ ${ }^{a}$ UCL Energy Institute, University College London, United Kingdom.
}

\begin{abstract}
The West African Power Pool (WAPP) aims to provide access to affordable electricity to all countries in the region by building electricity interconnections between countries and creating an integrated electricity market. In this study, we develop a multi-regional economic dispatch model of the West African power system, and quantify the impact of increasing cross-border electricity trading and renewable energy sources on: electricity generation cost, carbon emission, electricity supply and rapidly growing demand. Our results indicate that increasing cross-border electricity trading significantly reduces unserved electricity demand that comes from load shedding in the region. However, in the 2030 scenario where only existing and currently planned generation plants are operational, increased cross-border electricity trading increases electricity generation from heavy fuel and diesel power plants by $16 \%$ and $8 \%$ respectively. Consequently, this results in an increase in total electricity generation cost and carbon emission in the region. In two scenarios where all fourteen countries in the region are interconnected, average marginal costs in most of the net importing and net exporting countries decrease and increase respectively, due to insufficient generation capacities in several countries. A key finding from our study is that most of the planned interconnections by WAPP could be underutilized in 2030, thus providing an opportunity to integrate unexplored hydro and solar resources in the region.
\end{abstract}

\section{Highlights}

1. We developed an economic dispatch model for West African Power Pool countries.

2. The impacts of increased integration of hydro and solar plants are assessed.

3. Interconnections significantly reduce unserved electricity demand in the region.

4. Majority of the planned interconnections could be underutilized by 2030 .

\section{Keywords}

Cross-border electricity trading; electricity network modelling; interconnections; renewable energy; electricity market integration; West African Power Pool.

Word Count: 8050

\footnotetext{
*Corresponding author at Central House, 14 Upper Woburn Place, London, WC1H 0NN

Email address: omotola.adeoye.14@ucl.ac.uk

Phone number: +447462952106
} 


\section{Abbreviations}

$\mathrm{CO}_{2}$

Carbon Dioxide

ECOWAS

Economic Community of West African States

ECOWREX

ECOWAS observatory for Renewable Energy and Energy Efficiency ERERA

ECOWAS Regional Electricity Regulatory Authority

FO\&MCostg

Generation unit's g fixed operating and maintenance cost $(\$ / \mathrm{kW} /$ Year $)$

FuelPriceg

GenCap

Fuel price for generator $\mathrm{g}(\$ / \mathrm{GJ})$

Available generation (MW)

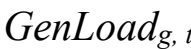

Generation unit's $\mathrm{g}$ dispatch level of in period $\mathrm{t}(\mathrm{MW})$

HeatRate $_{g}$

Lineflow

Heat rate for generator $\mathrm{g}(\mathrm{GJ} / \mathrm{MWh})$

Electricity flow on transmission line (MW)

Linemax

Maximum flow on transmission lines (MW)

MT

Medium Term

O\&M

Operation and Maintenance

OutageRate

PASA

Unavailable capacity due to an outage (MW)

Pmaxg

Projected Assessment of System Adequacy

Pming

Generation unit's g maximum generating level (MW)

Generation unit's g minimum generating level (MW)

RES

RMR

Renewable Energy Sources

Regional Market Rules

ST

Short Term

Unserved

Unserved demand during dispatch period t (MW)

WAPP

West African Power Pool

$V O \& M C o s t_{g}$

Generation unit's g variable operation and maintenance cost (\$/MWh) 


\section{Introduction}

The electricity sector in member countries ${ }^{1}$ of the Economic Community of West African States (ECOWAS) is currently experiencing several pressing challenges. Electrification rate of most ECOWAS countries was below 50\% in 2017 [1], with 171 million people out of 357 million people having no access to the electricity. High electricity generation cost is also a challenge, with eight out of fourteen countries in the region using diesel and heavy fuel generators to supply majority of its electricity demand. The region is endowed with abundant solar, hydropower, and gas energy sources, however the distribution of most of these resources is uneven [2]. While solar resource is abundant in all the countries, hydropower has its largest potential in Guinea located in the west of the region, followed by Nigeria and Ghana which are in the east and central part respectively. Natural gas reserves ${ }^{2}$ are mostly concentrated in the south in Nigeria, Cote d'Ivoire and Ghana. In 1999, under the auspices of ECOWAS, The West African Power Pool (WAPP) was established with the aim of providing access to affordable electricity through the creation of a regional electricity market, and the development of regional generating plants and interconnections between countries [3]. The potential benefits of electricity market integration between West African countries include; reducing electricity cost by increasing competition, achieving savings through reduced generation reserves, improved security of supply and efficient use of resources through generation pooling [4,5]. Despite these benefits and political cooperation to create a single regional electricity market, insufficient generating and interconnection capacities, limited investments and political instability in certain parts of the region are setbacks that have limited cross-border electricity trade in West Africa [6-8] .

In 2013, to ensure open access to interconnection capacity for the trade of electricity in a regional electricity market, ECOWAS member states agreed to the liberalisation of its national electricity sector under the ECOWAS directive C/DIR/1/06/13 [9]. However, by 2016 the directive has been implemented only in Ghana and Nigeria, with these two countries having a full separation of its generation, transmission and distribution sectors [10]. Burkina Faso, Guinea and Guinea Bissau are still fully vertically integrated, while the remaining nine countries are partial unbundled, having one national vertically integrated utility company and a few privately-owned generation companies. In 2015, as a step towards establishing a regulatory framework for the development and operation of the regional electricity market, The ECOWAS Regional Electricity Regulatory Authority (ERERA) approved the Regional Market Rules (RMR) for WAPP. Article 12 of the RMR proposes three phases of development for the integrated electricity market [11]. In the first phase (2016), trading is based on bilateral contracts between the countries or national market operators, while transmission tariff for each bilateral trade is based on flow-based pricing methodology [12]. In the second phase (20162020), bilateral trading will include wheeling of electricity through transit third countries and short term trading up to a few hours will be carried out through a day- ahead market [12]. The third phase will be a competitive market when spot market operations start, and all generation companies in the region can bid to supply electricity for each hour of the next day. Presently, interconnections exist only between nine countries and the WAPP plans to interconnect all 14 countries by 2025 with an estimated $6,109 \mathrm{~km}$ of high voltage transmission lines [7]. Furthermore, there is insufficient electricity generation capacity in most countries which results

\footnotetext{
The countries referred to in this study are the 14 members of the West African Power Pool, and they include: Benin, Burkina Faso, Cote d'Ivoire, Gambia, Ghana, Guinea, Guinea Bissau, Liberia, Mali, Niger, Nigeria, Senegal, Sierra Leone and Togo.

2 The gas reserves in Nigeria, Cote d'Ivoire and Ghana are 180.5 trillion cubic feet, 1 trillion cubic feet and 0.8 trillion cubic feet respectively.
} 
in the daily load shedding and electricity outages. Despite this generation insufficiency in some countries (e.g. Nigeria), they still export electricity because of their contractual obligations in the bilateral agreements with neighbouring countries (e.g. Benin and Niger).

The total electricity demand in 2016 for the region was $58 \mathrm{TWh}$ while the potential demand for the region in 2016 was estimated to be $112 \mathrm{TWh}$ [13], thus there was a potential unmet demand of up $54 \mathrm{TWh}$ in 2016. The estimated grid-connected demand for the region in 2030 is projected to be 244TWh [14], which is four times its 2016 recorded level. In order to supply this rapidly growing electricity demand and increase electricity access in West Africa through a regional electricity market, adequate generation and interconnection capacities are required. This study quantifies the impact of increasing grid-connected renewable energy sources and interconnections among West African countries on: electricity generation and demand, carbon emissions, electricity generation costs, and cross-border electricity trading. In 2017, ECOWAS launched the West African Solar Corridor initiative, with a target to increase the region's grid connected solar capacity from the existing $0.16 \mathrm{GW}$ to $10 \mathrm{GW}$ by 2030 [15]. In addition to this proposed solar corridor, this study analyses the integration of $5 \mathrm{GW}$ and $38 \mathrm{GW}$ of potential hydro and solar PV power plants respectively into the future interconnected electricity network. The large-scale integration of intermittent renewable energy sources (RES) increases the uncertainty of electricity supply balancing demand. Therefore, we identify potential pumped hydro energy storage (PHES) in the region and analyse its impact on the integration of the proposed intermittent solar PV power plants. This study answers the question of the role of RES and energy storage in meeting future electricity demand and facilitating electricity trading in an interconnected electricity network in West Africa, by evaluating six scenarios in the year 2030 .

The rest of the paper is structured as follows; Section 2 is the literature review and highlights the contribution of this paper to literature. Section 3 presents the development and the current regional electricity market structure in West Africa. Section 4 describes the interconnected electricity model developed using PLEXOS and the assumptions for each scenario. Section 5 discusses the modelling results from the six scenarios and sensitivity analysis on changes in electricity demand and fuel prices. Section 6 summarizes the main conclusions from the study and highlights future research plan.

\section{Literature Review}

There is a growing literature on the national and regional impacts of electricity market integration between countries. The study by Newbery et al. concludes that there are overall economic benefits from a fully integrated European electricity market with 32 countries despite the expensive costs of increasing interconnection capacities [16]. However, increasing crossborder trading could worsen the congestion problem currently faced by the national transmission network of some countries [17,18]. Pollitt reviewed the single electricity market in Europe over its 25-year existence, concluding that despite its impressive structural changes and increasing cross-border electricity trading, proven overall welfare benefits are moderate [19]. Zickfeld et al. suggest that an integrated electricity market between Europe and Middle East North Africa could result in up to $50 \%$ carbon dioxide $\left(\mathrm{CO}_{2}\right)$ reduction in both regions if renewable energy from the desert in North Africa is utilized [20]. Ochoa and Van Ackere analysed the impact of electricity market integration between Columbia and Ecuador, concluding that although integraton could reduce electricity supply cost and increase efficient use of energy resources, these benefits are dependent on the size of the countries and the interconnection capacities between them [21]. Timilsina and Toman analysed the effect of 
increasing cross-border electricity trade in an integrated South Asia electricity market, and showed that there will be a significant decrease in electricity generation cost and less coal plants capacity in the region [22]. Electricity market integration is expected to lead to the convergence of electricity prices, mostly with an increase and decrease in the exporting and importing countries respectively. Ouriachi and Spataru highlights a high correlation coefficient of electricity prices between countries in four integrated electricity market in Europe [23]. Despite the obvious benefits of electricity market integration, it is important to note that there can be negative impacts to some market participants as a result of integration. For instance, Finon and Romano stresses that when electricity market integration occurs, consumers in countries with substantial amount of lower cost generation infrastructures experience more increase in their electricity bills in comparison with countries with high cost capacities [24]. Spiecker et al. carried out an assessment of interconnection investment decisions on the overall welfare of 30 countries in the European integrated electricity markets [25]. Results suggest that there is an increase in total welfare gains, however majority of the welfare gains will benefit only a few countries while some countries are negatively impacted with losses from their investments.

Given the low marginal generation cost of renewable energy power plants, electricity market integration provides the opportunity to reduce fossil fuel generation and integrate large scale RES that are widely spread between countries using interconnection infrastructures. Otsuki et al. investigated the economic feasibility of integrating renewable energy from Gobi desert Eastern Russia and increasing interconnections in North East Asia, with the study concluding there can be potential benefits due to reduced fuel costs [26]. Cleary et al. examined the impact of large amounts of electricity generated from wind energy on the British and Irish integrated electricity market, and results from the study showed a decrease in wholesale marginal prices in the two countries [27]. However with the increasing integration of intermittent RES, electricity market integration face challenges such as ;unplanned overproduction resulting in congestion in interconnection lines and disparity between demand and supply [28,29]. Results from the model in Brancucci Martinez-Anido et al. show that with increasing integration of wind energy, there is a decrease in electricity prices and an increase in electricity price volatility [30]. Interconnection infrastructures also play a significant role in integrating electricity markets and facilitating cross-border electricity trading between countries, this has led to several investigations on extensions to interconnections. Stich et al. concluded that new cross border transmission lines between Indonesia, Malaysia and Singapore in a scenario of low $\mathrm{CO}_{2}$ emissions could moderately reduce total cost of generation in the region [31]. Giesbertz and Mulder examined the interconnections between Netherlands and Norway (NorNed) and Netherlands and United Kingdom (BritNed), and reveal that extension to these grid will increase the trade and competition in the electricity market [32]. However, the authors noted that the installation of new power plants closer to load centres could be a least cost substitute to these extensions. The study by Malaguzzi Valeri showed that to achieve an integrated market between Great Britain and Ireland, the capacity of the interconnector required is mainly dependent on the differences between the types of generation infrastructures in the two countries [33].

Following numerous national targets to increase share of electricity generated from RES, there have been several studies that have analysed the impact of large scale energy storage (LSES) in low carbon electricity systems [34-41]. Results from [34,41] show that a power grid having at least $80 \%$ of its electricity generation from RES, requires storage in order to meet demand. Grid connected LSES in systems with increasing integration from intermittent RES are shown to have the benefit of reducing; operational costs [39,42,43], carbon emission [44], back-up 
fossil power plants capacity $[38,45,46]$, cycling of conventional power plants $[47,48]$, and deferring investment in transmission line extensions [47,49]. On the other hand, LSES is shown to reduce the profitability of electricity generators [45] and increase total system cost because of its high investment cost [35,45,50-52]. However, despite the highlighted benefits and drawbacks of grid connected LSES, it is important to note that its level of impact is contingent on the electricity mix, RES integration level, fuel price, market structure and transmission network of the analysed system [36,44,46]. A few studies have assessed the role of LSES in interconnected electricity networks between countries when high amounts of RES are integrated in the network. Brancucci Martínez-Anido et al. investigated the impact of crossborder transmission lines on PHES in the interconnected European network by 2025 , and concluded that the need for PHES is reduced when there is an increase in cross-border transmission lines capacities [43]. Fürsch et al quantified the benefits of developing the interconnected grid in Europe by 2050 for optimal utilisation of abundant RES and concluded that in a scenario where grid extensions are hindered, storage infrastructures are built to a large extent [53]. Huber et al. quantified the capacities of generation, transmission and storage infrastructures in a low carbon South East Asia system by 2050 , and concluded that battery storage only plays a significant role in strict low emission constraints scenarios [54]. Bogdanov and Breyer showed that the capacity and type of storage technology required in a $100 \%$ renewable North East Asia energy system, is dependent on the transmission interconnections between countries and the utilized RES [55].

To our knowledge, there have been very few studies that analysed the impact of significant integration of RES and LSES in a fully interconnected electricity grid in West Africa. Hydro power is the only RES taken into account in [56] and [57], with both studies concluding that trading in an integrated electricity market could result in electricity generation costs savings of $20 \%$ over a 10 -year period and $38 \%$ over a 20 -year period respectively. Adeoye and Spataru evaluated the integration of grid connected solar PV plants in the region and presented annual savings of up to $40 \%$ in electricity generation cost [58]. Miketa and Merven considers the integration of various RES in a regional electricity market in West Africa, with results from the model used suggesting that average cost of electricity generation in the region could reduce by up to 7\% [59]. However, their model of the interconnected electricity network in West Africa does not carry out short term economic dispatch of power plants. These aforementioned studies on West Africa's interconnected electricity grid identify the potential economic benefits of large-scale RES integration in the centralized grid. However, the temporal and spatial variability of RES, have not been considered in these studies. Therefore, we developed an hourly multi-regional model that captures the impact of RES variability on the interconnected grid.

This paper contributes to the existing literature in three ways. First, by developing a highspatial economic dispatch model of West Africa's interconnected electricity system, that divides 14 countries into 33 regions. We also model all 87-grid connected solar and wind power plants in the region individually in order to represent the intermittent characteristics of RES in different locations in each country. Second, we investigate the role of grid connected electricity storage in the future West African interconnected electricity network. Finally, we present a comprehensive analysis of the techno-economic impact of region-specific RES and electricity market integration on each West African country. 


\section{Regional electricity market in West Africa}

The plan to create a regional electricity market in West Africa was initiated in 1978 when Article 26 of the ECOWAS Treaty was implemented. WAPP was finally established in 1999 by ECOWAS to develop regional generation and transmission infrastructures sufficient to meet projected demand, while ERERA was created in 2008 to design and regulate a regional electricity market. Trading of electricity is currently carried out between nine countries ${ }^{3}$ which are adjacent to each other as shown in Figure 1, and the major exporters are Nigeria, Ghana and Cote d' Ivoire and Mali due to their comparatively cheaper base load generation of hydropower and natural gas plants. Cross-border trading is based on ERERA approved bilateral agreements between countries or private generation companies in the case of countries with liberalised electricity sector. The price for utilization of interconnection capacity is included in the whole sale electricity price agreed on in the bilateral contracts. Allocation of interconnection capacity is carried out by the owners of the infrastructures on a yearly or monthly basis, depending on the agreements in bilateral contracts. After long term trades are considered, the remaining available interconnection capacity is made accessible to other market participants for short term trading on a first-come-first-served approach. In situations where cross-border flows exceeded the available capacity and lead to congestion, curtailment is implemented. With more countries in the region starting the process of liberalising its electricity market, it is expected that there will be more market participants and market coupling will be implemented in allocating interconnection capacity.

The electricity generation mix in West Africa in 2016 was dominated by natural gas plants with a share of $65 \%(12.2 \mathrm{GW})$, followed by $24 \%(4.5 \mathrm{GW})$ from hydro, $9 \%(1.8 \mathrm{GW})$ from oil and the remaining $2 \%(0.04 \mathrm{GW})$ of the mix is from coal, solar and wind plants. Installed solar and wind plants in West Africa are mostly off-grid systems in communities that are not

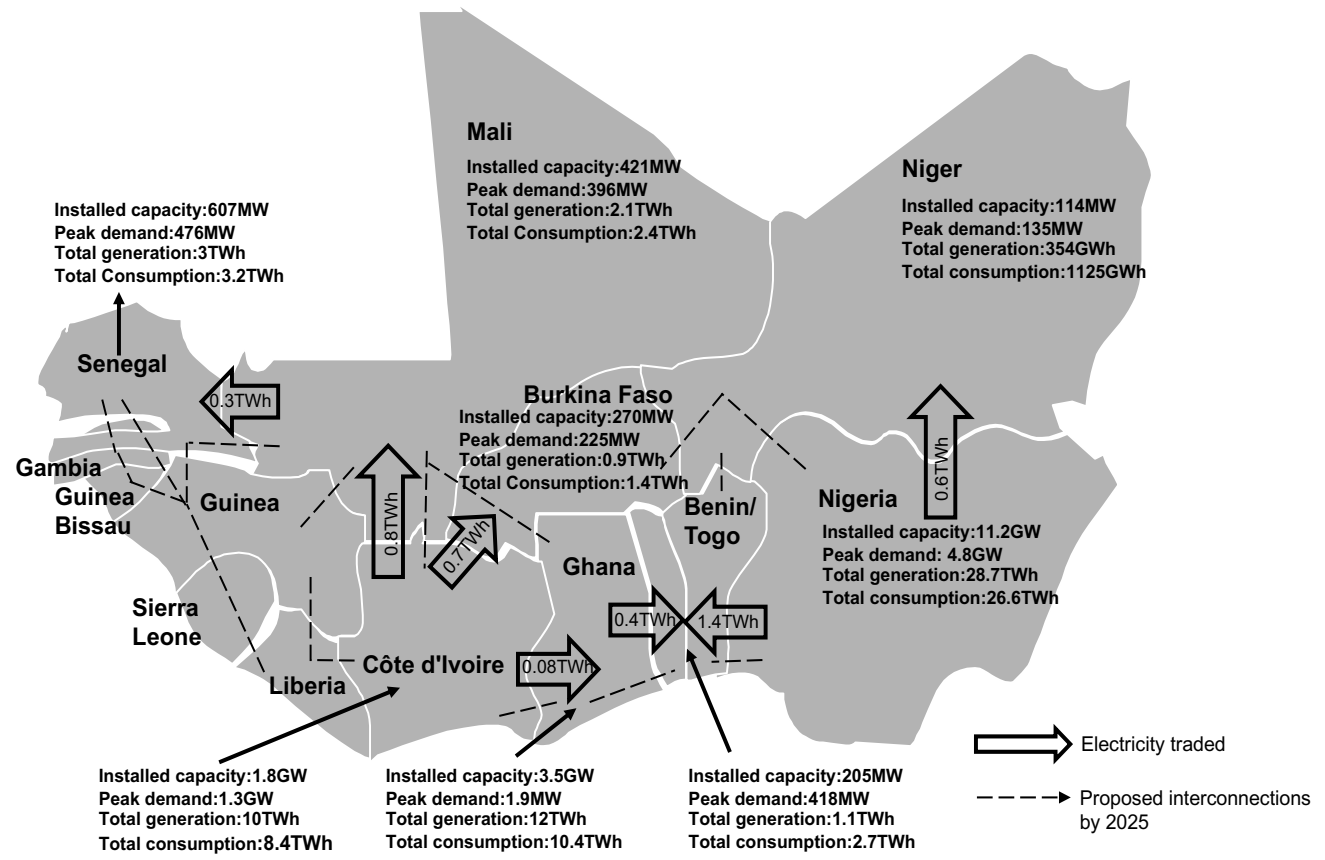

Figure 1. Electricity flow in West African countries in 2016.

\footnotetext{
${ }^{3}$ Benin, Burkina Faso, Cote d'Ivoire, Ghana, Mali, Niger, Nigeria, Senegal, and Togo
} 
connected to the grid. Diesel which is used in 10 countries is the most commonly used resource, and is the main source of electricity generation for up to 7 countries which is reflected in the high tariff rates [60] in countries like Liberia, Guinea Bissau and Burkina Faso as shown in Figure 2. Interconnections have provided countries like Benin, Mali, Niger, Senegal and Togo with high cost generating infrastructures an opportunity to import comparatively lower cost electricity from neighbouring countries. Electricity exchange in 2016 was $4 \mathrm{TWh}$ and accounted for $9 \%$ of the total electricity generated in the region, as presented in Figure 3. Electricity trading between countries in West Africa has been limited due to insufficient generating capacities as majority of the exporting countries have a supply-demand gap and are unable to meet rapidly growing demand. Cross-border electricity flow was significantly reduced in 1998 and 2007 due to the drought that affected hydro power generation in Cote D'Ivoire, Ghana, and Nigeria. Vandalism on several natural gas pipelines in Nigeria in 2012 also significantly reduced electricity generation in the both Nigeria and Ghana, and thus affected electricity trade to Benin and Togo.

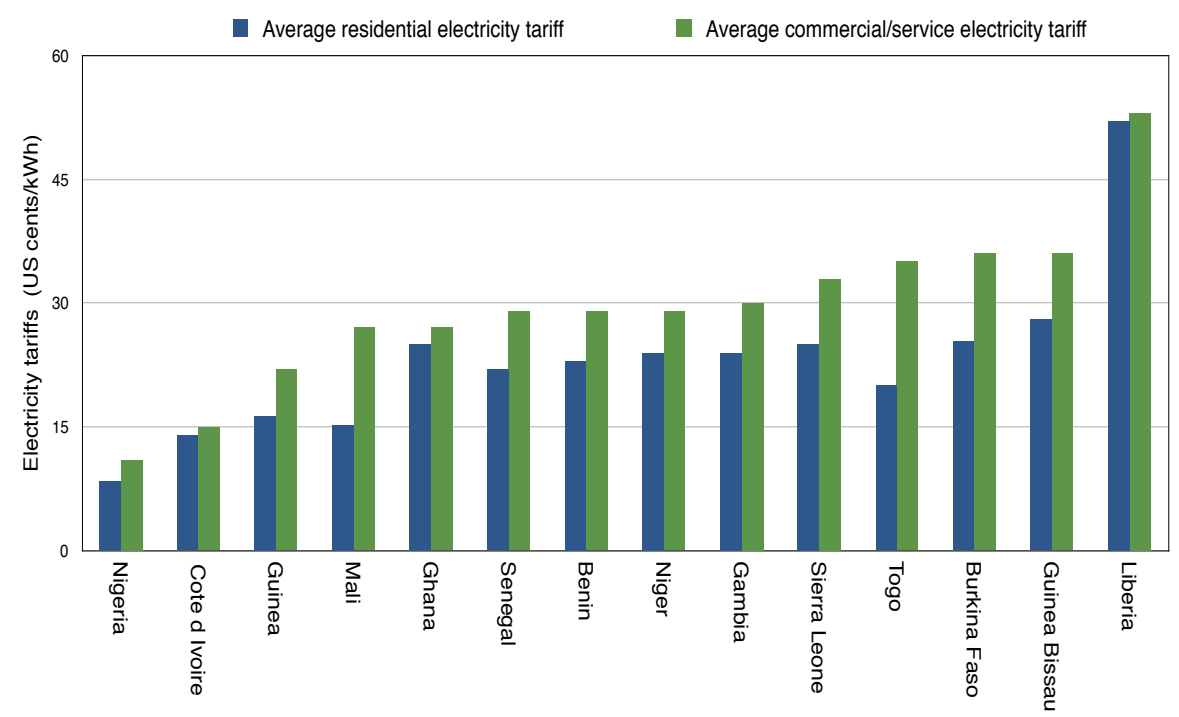

Figure 2. Electricity Tariffs in West African countries in 2016.

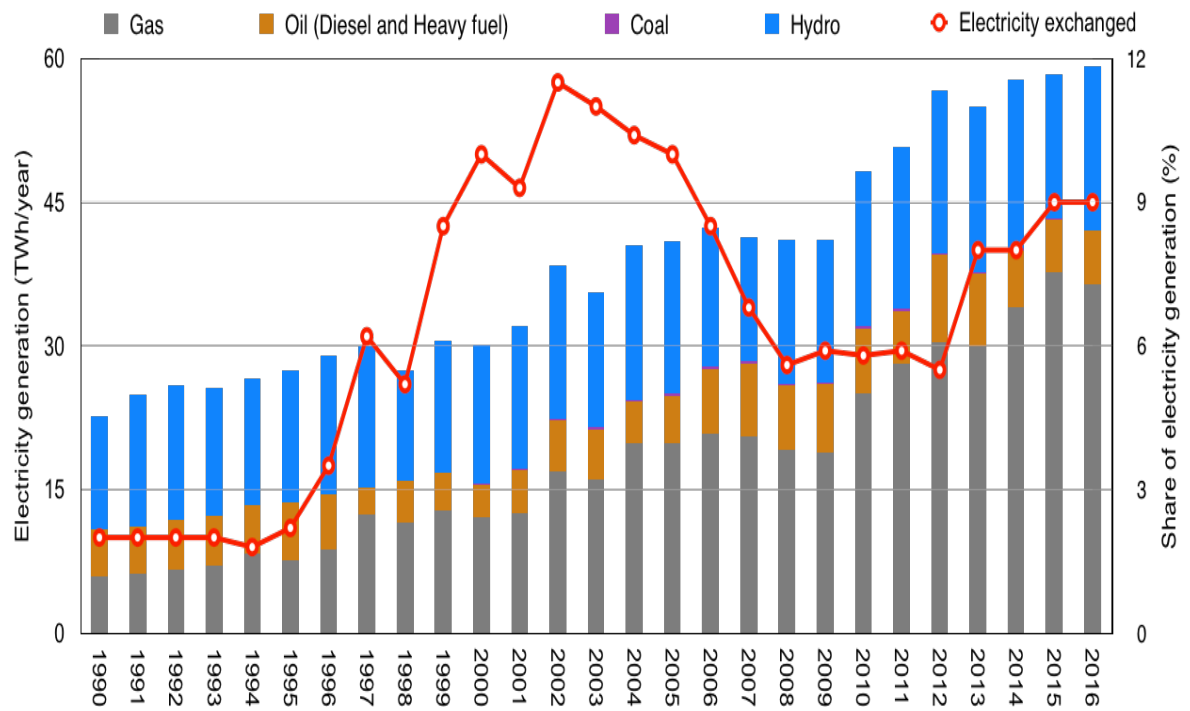

Figure 3. Electricity generation by technology and electricity exchange in West Africa (1990 - 2016). 


\section{Methodology}

\subsection{Modelling tool}

To quantify the impact of increasing RES integration and cross-border electricity trading in West African region, PLEXOS modelling tool is used in this study. PLEXOS Integrated Energy Modelling tool [61] is developed by Energy Exemplar for the planning, simulation and optimization of electricity systems. The optimization of the West African power system is carried out in 3 sequential phases, thus allowing the output from the previous phase to be used as input in the next phase. The first phase is the Projected Assessment of System Adequacy (PASA) phase, which accounts for the availability of power plants in the year, by scheduling maintenance outages based on power plant's outage rates and mean time to repair. The PASA phase also takes into account the peak demand periods and reserve margin in each country. The second phase is the Medium Term schedule phase, which decomposes the annual generation constraints of hydro power plants into weekly constraints for the third phase. The third phase is the Short Term (ST) schedule phase that optimizes the economic dispatch of power plants to meet demand every hour in a year, by using rounded linear relaxation programming. The ST schedule phase minimize the total generation cost in the power system which includes; variable Operating and Maintenance (O\&M) costs and fuel cost, subject to availability of power plants and defined constraints of power plants and transmission lines. The objective function of the model is to minimize the total generation cost which includes fuel costs, fixed and variable O\&M costs in each simulation time step Eq. (1).

$$
\begin{aligned}
& \operatorname{Min}_{y}\left(\text { FO\&MCost }_{g} \text { X Pmaxg }\right)+\sum_{t}\left(\text { GenLoad } _ { g , t } X \left(\left(\text { FuelPrice }_{g} \text { X HeatRate }_{g}\right)+\right.\right. \\
& \text { VO\&MCost } \left.\left._{g}\right)\right)
\end{aligned}
$$

Where FO\&MCost $t_{g}$ is the generation unit's g fixed operating and maintenance cost (\$/kW/Year), Pmax $_{g}$ is the generation unit's g maximum generating level (MW), Pmin $_{g}$ is the generation unit's g minimum generating level (MW), GenLoad ${ }_{g} t$ is the generation unit's g dispatch level of in period $\mathrm{t}_{\mathrm{t}}(\mathrm{MW})$, FuelPrice $_{\mathrm{g}}$ is the fuel price for generator $\mathrm{g}(\$ / \mathrm{GJ})$, HeatRate $_{\mathrm{g}}$ is the heat rate for generator $\mathrm{g}(\mathrm{GJ} / \mathrm{MWh})$, and VO\&MCost $\mathrm{g}$ is the generation unit's $\mathrm{g}$ variable operation and maintenance cost $(\$ / \mathrm{MWh})$. The objective function is subject to four constraints Eqs. (2) - (5). The first constraint is that total electricity generation meets demand every hour of the year when generation capacity level is sufficient. For the second constraint, maximum capacities and minimum stable levels of generation plants are not exceeded. For the third constraint, the electricity flow in interconnection lines is limited to its maximum capacity. The fourth constraint enforces the availability of generation plants which is determined by the annual outage rates and mean time to repair which is assumed to be $48 \mathrm{hrs}$.

$\sum_{t}($ GenLoad + Unserved $)=$ Demand $_{t}$

Pming $\leq$ GenLoadg $\leq$ Pmaxg

Lineflow $\leq$ Linemax

GenCap $=$ Pmaxg-Outage

Where Unserved is the unserved demand during dispatch period t (MW), Lineflow is the electricity flow on transmission line (MW), Linemax is the maximum flow on transmission 
lines (MW), GenCap is the available generation (MW), and OutageRate is the unavailable capacity due to an outage (MW).

\subsection{Modelling approach and data assumptions}

The model developed in PLEXOS for the West African region has a temporal resolution of 1 hour in 2030 and a spatial resolution of 33 sub-regions. Each sub-region's location corresponds to the interconnection point in each of the 14 countries in this study. By dividing the entire West African region into 33 sub-regions, we have increased the spatial resolution of the regional model when compared to previous models of the West African interconnected electricity network that only have 14 regions [56,57,59]. This methodology approach enables us to account for the hourly intermittent characteristics of each of the RES in various sites in each country. The dispatchable power plants in each country are aggregated based on their type of technology and proximity to their closest sub-region. Planned interconnections between all 14 countries are expected to be fully installed and in operation by 2023 , however there have been noted delays due to financial constraints and re-evaluation of projects by national authorities [7]. Therefore, to account for these delays the time horizon for this study is 2030 .

\subsubsection{0 electricity demand}

2030 hourly electricity demand for each country was obtained from [62]. The hourly demand values in each country is an aggregate of the electricity demand in both the residential and nonresidential sectors. Demand in the residential sector was forecasted based on an increase in electricity access rates and appliance ownership, while demand in non-residential sector accounts for population and GDP growth. $75 \%$ of the region's demand is assumed to be met by grid connected supply by 2030 , with the remaining demand met with mini grids and standalone systems [14]. The 2030 grid connected demand in the region is assumed to be 196TWh with a peak demand of $42 \mathrm{GW}$. Further information on the methodology for forecasting the 2030 hourly demand can be found in [62]. It is important to note that Nigeria's forecasted 2030 electricity demand is estimated to be $115 \mathrm{TWh}$, and therefore accounts for approximately $60 \%$ of the total forecasted demand in the West African region. The assumed 2030 annual and peak demand for each country are presented in Table A.1.

\subsubsection{Thermal power plants}

The thermal power plants (coal, gas, diesel, heavy fuel and biomass) are modelled by defining their heat rate, installed capacity, capacity factor, minimum stable levels, ramp rate and emission rates. Data on the existing and planned generation capacity in all countries is obtained from ECOWREX's database [63]. The capacity factor assumed for each type of power plant is based on the 2016 average values obtained from WAPP information and coordination centre [64]. To account for grid stability in the electricity network, the ramp rates of the thermal and hydro power plants have been modelled. In the event of sudden decrease in electricity production from solar and wind power plants due to the fluctuating nature of their resources, available power plants respond and increase their load levels according to their modelled ramp rates. The outage rates include both planned maintenance and forced outages due to sudden problems with the plants. Carbon emission rate, heat rate, ramp rates, minimum stable levels, and outage rates assumed in this study are presented in Table A.2. [11,64,65]. The economic parameters assumed for the different electricity generation technologies are presented in Table A.3. $[11,69,70,71]$. 


\subsubsection{Renewable power plants}

Unlike the thermal and hydro power plants, wind and solar PV plants are modelled individually based on their installed capacity and hourly output profiles. The hourly output assumed for each of the wind power plants are taken from [69], which uses National Aeronautics and Space Administration's MERRA-2 dataset. The wind plants are assumed to have a hub height of 80meters, while the turbine model power curve chosen is based on the installed turbine. The hourly outputs assumed for each of the solar PV plants are taken from [70] using the Climate Monitoring Satellite Application Facility (CM-SAF) database. The solar concentrated solar power (CSP) plants are modelled by defining their hourly electricity output, storage and loss levels which are calculated using National Renewable Energy Laboratory's System Advisor model [71]. The CSP plants are assumed to use cylindrical parabolic collectors, thermal oil as its heat transfer liquid, molten salt for thermal storage, have a capacity factor of $35 \%$ and 5.5 hours of storage. Hydro power plants which include both dam and run-off-the river power plants, are modelled by defining their installed capacities and maximum annual energy production levels which are calculated using Eq. (6).

$E=P \times C F \times H$

Where $\mathrm{E}$ is the maximum annual energy generated $(\mathrm{MWh}), P$ is the installed capacity of power plant (MW), $C F$ is the capacity factor of the power plant and is based on their average capacity factor in 2016 [64], $H$ is the total number of hours in the year (8760).

\subsubsection{Interconnections and electricity storage}

The existing and planned 25 interconnection lines between the 14 countries (Figure 1) are modelled by their maximum flow capacity and losses $[13,72,73]$. Using these two parameters to define the interconnection lines simplifies them as transport models having no resistance and reactance. Detailed assumptions on the maximum capacity and losses for all the 25 interconnection lines used in this study are listed in Table A.4. The PHES are modelled by defining their installed capacity and maximum storage levels which are calculated using Eq. (7). Assumptions on the four PHES modelled in this study are presented in Table A.5.

$E=\rho \times q \times g \times h \times t \times \mu$

Where $\mathrm{E}$ is the maximum storage level $(\mathrm{GWh}), \rho$ is water density $\left(1000 \mathrm{~kg} / \mathrm{m}^{3}\right), q$ is the water flow $\left(\mathrm{m}^{3} / \mathrm{s}\right)[74], g$ is the acceleration of gravity $\left(9.81 \mathrm{~m} / \mathrm{s}^{2}\right), h$ is the height of falling water (m), $t$ is the discharge time which is assumed to be 8 hours, and $\mu$ is the pump efficiency which is assumed to be $80 \%$ efficiency [75].

\subsection{Scenarios}

To quantify the technical and economic impact of integrating large scale RES and increasing interconnections in West Africa, we examined six scenarios as summarized in Table 1. The installed capacities for all six scenarios are presented in Table A.6. In the Base scenario, in addition to existing capacities, we assume all national and regional power plants currently in planning phase are fully operational resulting in a total regional installed capacity of $44 \mathrm{GW}$. This is an additional $25 \mathrm{GW}$ capacity in comparison to the currently installed capacity of 19 GW in 2017 [63]. In the Base scenario, gas power plants have the highest share of $36 \%$, followed by hydro, coal and diesel power plants with $28 \%, 6 \%$ and $5 \%$ share respectively. In 
the Base scenario we assume the West African solar corridor road map targets [76] are achieved by 2030. The targets set for each country will increase the region's grid connected solar capacity to $10 \mathrm{GW}$ by 2030 and are presented in Table A.7. The distribution of these targets in the different countries is presented in Appendix A.1.

In addition to the installed capacities in the Base scenario, the Hydro scenario seeks to utilize the unexploited hydro resources in the West African region. The potential run-of-the-river hydro power plants identified in the WAPP master plan [13] are assumed to be in operation by 2030 and their capacities are presented in Table A.7. These potential hydro power plants (5 GW) are mostly located in the Gambia, Konkoure, Niger and Senegal rivers. Following the integration of $10 \mathrm{GW}$ of solar power plant in the interconnected grid, the Hydro scenario uses potential large scale pumped hydro power plants as a storage option to balance the intermittent solar PV power plants. The selection process of the four potential pumped hydro plant sites are discussed in Appendix A.2.

The Solar scenario seeks to meet the ECOWAS renewable energy policy target to increase renewable energy capacity (excluding hydro) in the region to $20 \%$ of the peak demand in 2030 by increasing solar PV capacities. Given the estimated peak demand of $42 \mathrm{GW}$ and large scale solar PV capacity factor of 22\% [65], all the 73 grid connected solar PV plants in the Base and Hydro scenarios are increased four times resulting in an additional $38 \mathrm{GW}$ as highlighted in Table A.6. The Base. Hydro, and Solar scenarios assume only the existing eight interconnections between nine countries are operational in 2030. On the other hand, the Base Newlines, Hydro Newlines, and Solar Newlines scenarios assumes all fourteen countries are interconnected in 2030, with twenty-five existing and proposed interconnections fully operational.

Table 1. Summary of scenarios.

\begin{tabular}{|c|c|c|c|c|c|c|}
\hline Scenario & Base & Base Newlines & Hydro & Hydro Newlines & Solar & Solar Newlines \\
\hline $\begin{array}{l}\text { Thermal power } \\
\text { plant capacities }\end{array}$ & \multicolumn{6}{|c|}{ Existing and planned gas, coal, diesel and heavy fuel power plants $(22 \mathrm{GW})$. } \\
\hline $\begin{array}{l}\text { Hydro power } \\
\text { plant capacities }\end{array}$ & \multicolumn{2}{|c|}{$\begin{array}{l}\text { Existing and planned hydro power } \\
\text { plants(12.3GW). }\end{array}$} & \multicolumn{4}{|c|}{$\begin{array}{l}\text { In addition to Base scenario capacities, potential hydro power plants } \\
\text { identified in [13] }(5 \mathrm{GW}) \text { and PHES plants }(1 \mathrm{GW}) \text { are included. }\end{array}$} \\
\hline $\begin{array}{l}\text { Solar power } \\
\text { plant capacities }\end{array}$ & \multicolumn{4}{|c|}{$\begin{array}{l}\text { Existing and planned solar power plants which includes PV plants }(8.6 \mathrm{GW}) \\
\text { and CSP plants }(0.6 \mathrm{GW}) \text {. }\end{array}$} & \multicolumn{2}{|c|}{$\begin{array}{l}\text { In addition to the Base and Hydro } \\
\text { scenario capacities, solar PV } \\
\text { capacities to meet ECOWAS } 2030 \\
\text { renewable energy policy target are } \\
\text { included [14] (38GW) }\end{array}$} \\
\hline $\begin{array}{l}\text { Other } \\
\text { renewable } \\
\text { power plant } \\
\text { capacities }\end{array}$ & \multicolumn{6}{|c|}{ Existing and planned wind and biomass power plants $(0.6 \mathrm{GW})$. } \\
\hline $\begin{array}{l}\text { Interconnection } \\
\text { capacities }\end{array}$ & $\begin{array}{l}\text { Existing } \\
\text { interconnections } \\
(2.5 \mathrm{GW})\end{array}$ & $\begin{array}{l}\text { Existing and } \\
\text { proposed } \\
\text { interconnections } \\
(9.6 \mathrm{GW})[14]\end{array}$ & $\begin{array}{l}\text { Existing } \\
\text { interconnections } \\
(2.5 \mathrm{GW})\end{array}$ & $\begin{array}{l}\text { Existing and } \\
\text { proposed } \\
\text { interconnections } \\
(9.6 \mathrm{GW})[14]\end{array}$ & $\begin{array}{l}\text { Existing } \\
\text { interconnections } \\
(2.5 \mathrm{GW})\end{array}$ & $\begin{array}{l}\text { Existing and } \\
\text { proposed } \\
\text { interconnections } \\
(9.6 \mathrm{GW})[14]\end{array}$ \\
\hline
\end{tabular}

\section{Results}

\subsubsection{0 electricity generation and demand}

The regional generation mix for 2016 and the 6 simulated scenarios in 2030 are shown in Figure 4. Electricity generation from coal plants have no significant share in 2016 while in 2030 they have a share between $7 \%$ and $10 \%$ in the different scenarios. 


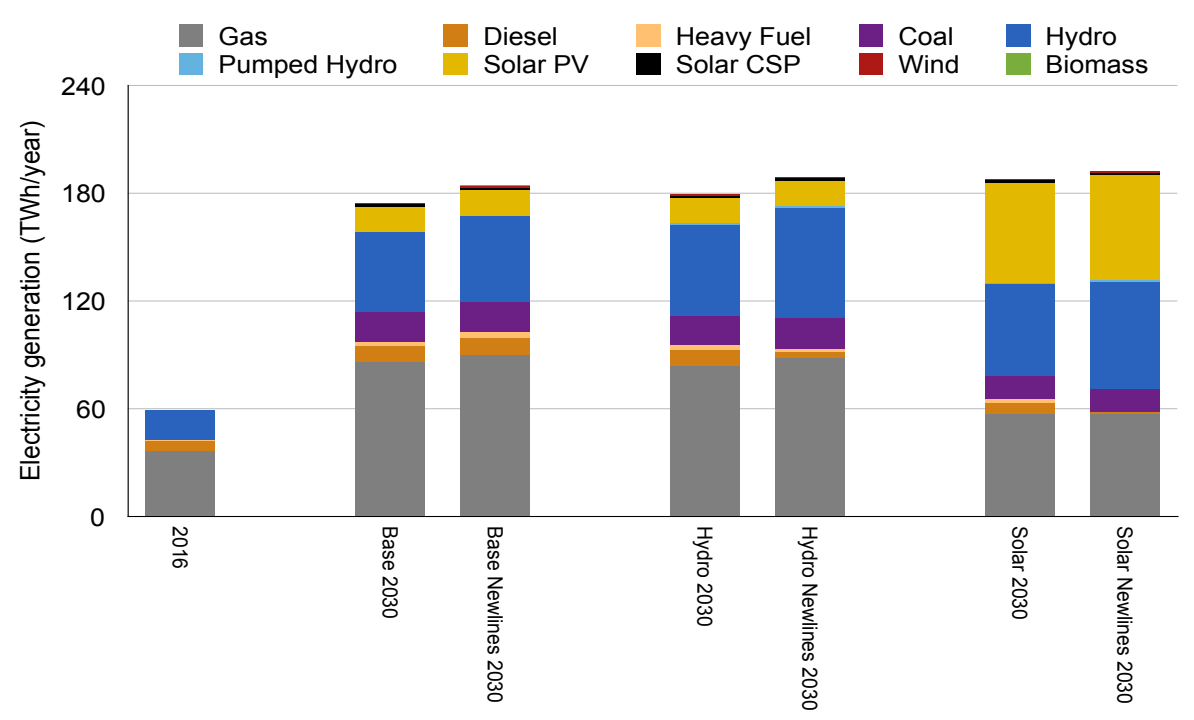

Figure 4. Electricity generation by technology in 2016 and 2030 Scenarios.

This is due to the $2.5 \mathrm{GW}$ capacities currently in planning phase by Cote d'Ivoire, Niger, Nigeria and Senegal, to meet their rapidly growing electricity demand. In 2016, except for hydro plants having a $29 \%$ share in the supply mix, renewable technologies have no share in the mix. By 2030, in the Base scenario hydro power plants share decreases to $25 \%$, while the collective share of the other renewables (solar PV, wind and biomass) increases from $0 \%$ to $10 \%$. The regional electricity mix in the Base scenario is $49 \%$ from gas plants, $10 \%$ from coal, $5 \%$ from diesel, and 1\% from heavy fuel. Additional interconnections in the Base Newlines scenario results in a $16 \%, 9 \%, 8 \%$ and $5 \%$ increase in electricity generation from heavy fuel, hydro, diesel, and gas plants, with no significant changes to coal plants and the other RES plants. This is due to insufficient generation capacities to meet demand in Burkina Faso, Gambia, Liberia, Senegal and Togo, resulting in an increase in electricity import from other countries.

Given the comparatively lower marginal cost of electricity generation from RES plants, the increased RES in the Hydro and Solar scenarios leads to a decrease in fossil fuel generation.

In the Hydro scenario, the $6 \mathrm{GW}$ additional capacity of hydro plants increases the share of hydro generation to $28 \%$, and reduces electricity generation from heavy fuel, diesel, and gas plants by $11 \%, 5 \%$ and $2 \%$ respectively in comparison to the Base scenario. Similar to the Base scenario, gas plants remain the main source of electricity generation in the Hydro scenario with $83 \mathrm{TWh}$. On the other hand, the $38 \mathrm{GW}$ additional capacity of solar PV plants in the Solar scenario reduces gas plant generation to $57 \mathrm{TWh}$, while electricity generation from diesel, heavy fuel and coal plants reduces by $92 \%, 90 \%$ and $20 \%$ respectively in comparison to the Base scenario. Additionally, in the Solar scenario, solar PV generation increases significantly to $30 \%$. Cross-border electricity trading in the Hydro Newlines, and Solar Newlines scenarios reduced generation from diesel and heavy fuel plants significantly, and were substituted mostly with electricity imports from coal and hydro plants.

In the Hydro Newlines scenario, with new interconnections added to the grid, comparatively low-cost electricity from Cote $d$ Ivoire is used to increase pumping operations of PHES in Ghana during off-peak periods. Consequently, increasing electricity generation from Ghana's PHES during peak demand periods. With additional $38 \mathrm{GW}$ of solar PV plants in the Solar scenario, all the four PHES in the region increases its pumping and generation operations, with Ghana having the maximum increase as generation from solar PV displaces generation from 
high-cost diesel plants during the day. In the Solar Newlines scenario, Sierra Leone is now interconnected to Guinea and Liberia and exports low-cost electricity generated from its PHES. Table A. 8 shows the annual generation from the pumped hydro power plants in four different scenarios with different levels of solar PV integration and interconnection capacities.

The share of annual demand in each country that is unserved due to insufficient generation capacities in the six scenarios, are presented Figure 5. The countries with the highest share of their annual demand unmet were: Liberia (39\%) in the Base, Togo (12\%) in the Base Newlines, Nigeria (4\%) in the Solar Newlines, and Gambia in the Hydro (38\%), Hydro Newlines (7\%) and Solar (27\%) scenarios. Electricity generation increases in the three scenarios with additional interconnection capacities. Interconnections provide countries with sufficient reserve margin at certain periods an opportunity to export electricity to countries with unserved electricity demand. A total of 9.6 TWh, 9.3 TWh and 4 TWh of unserved energy were met in the Base Newlines, Hydro Newlines, and Solar Newlines scenarios in comparison with the Base, Hydro, and Solar scenarios respectively. Ghana has the highest unserved demand met because of additional interconnections. The unserved demand in Ghana decreases by 4.7TWh in the Base Newlines in comparison to the Base scenario, by 4.1TWh in the Hydro Newlines in comparison to the Hydro scenario, and by 1.3TWh in the Solar Newlines in comparison to the Solar scenario. It is important to note that these unserved demands met in Ghana only account for $16 \%, 14 \%$ and $5 \%$ of its 2030 electricity demand.

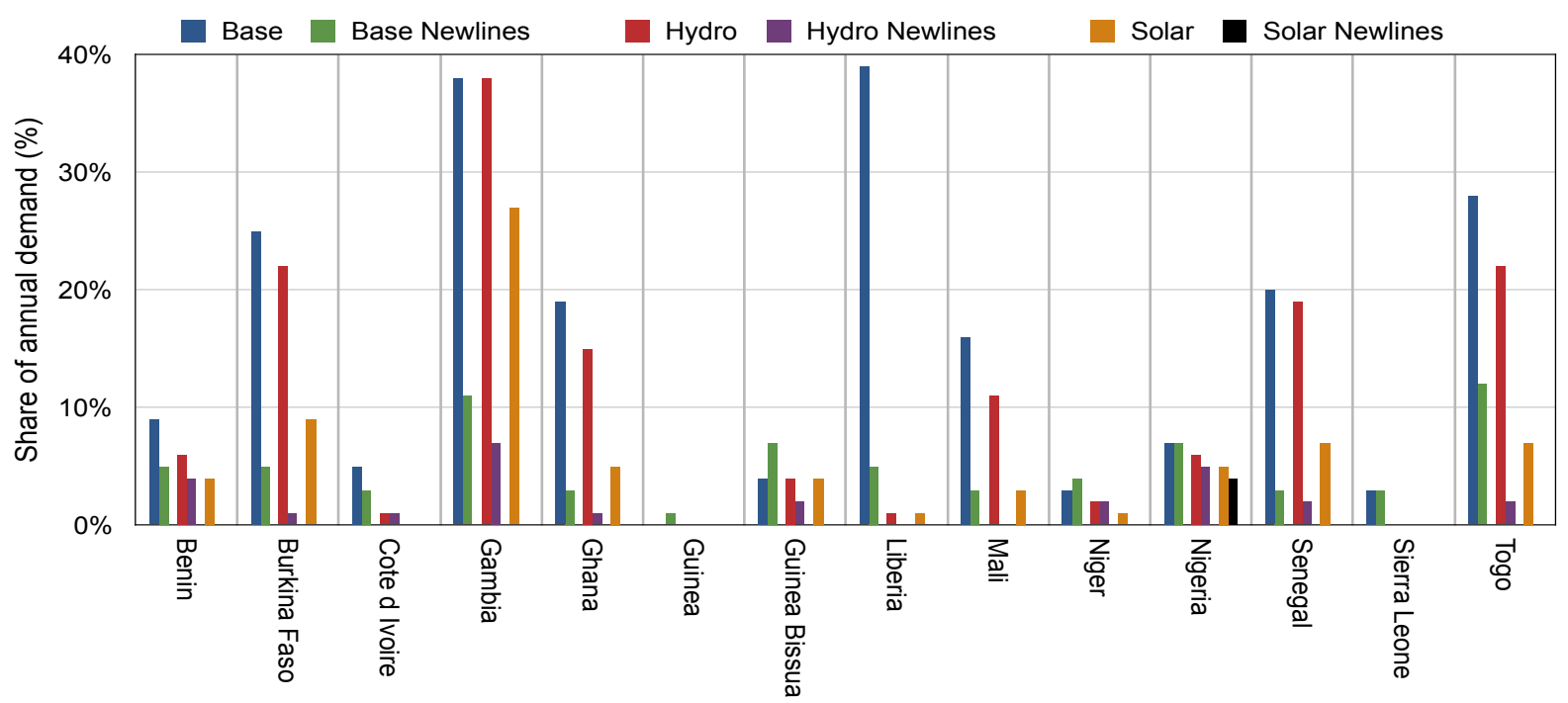

Figure 5. Unserved electricity demand in the 2030 simulated scenarios.

The annual regional $\mathrm{CO}_{2}$ emissions from coal, diesel, heavy fuel and gas plants in the power system is shown in Figure 6. The $44 \mathrm{GW}$ additional capacity of RES reduces $\mathrm{CO}_{2}$ emissions by $31 \%\left(17 \mathrm{MtCO}_{2}\right)$ in comparison to the Base scenario. In all the scenarios examined, gas plants are the dominant contributor to the $\mathrm{CO}_{2}$ emission, followed by coal plants, diesel plants and heavy fuel plants. In the Base Newlines scenario, the total $\mathrm{CO}_{2}$ emission is $55.5 \mathrm{MtCO}_{2}$, which is $5 \%$ higher than the $\mathrm{CO}_{2}$ emission in the Base scenario because of increased crossborder electricity trading. The highest increase is from gas plants $(65 \%)$, next is diesel $(19 \%)$, then heavy fuel $(10 \%)$, and coal (4\%). Cross-border electricity trading allows countries with insufficient generation capacities to import electricity from countries with available reserve margin despite the higher generation cost, as in the case of diesel and heavy fuel plants. 


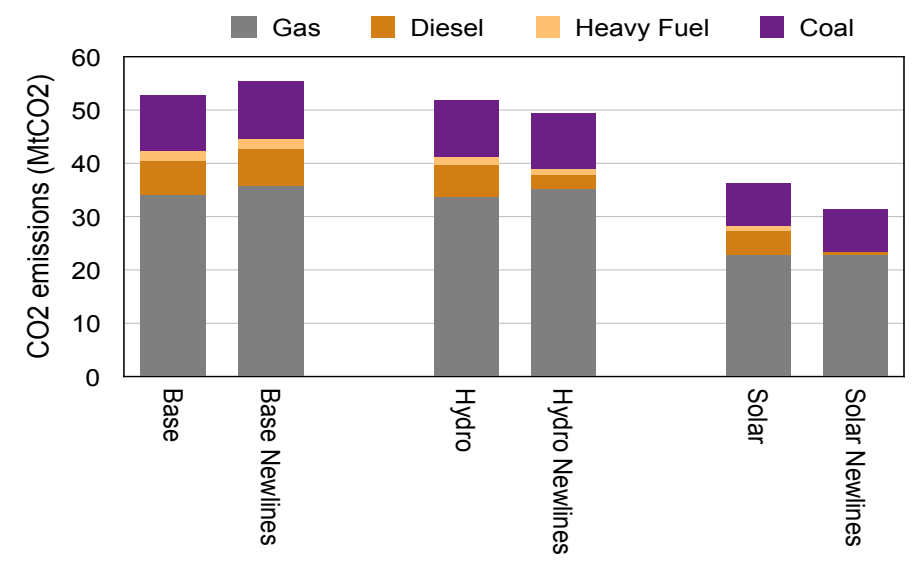

Figure $6 . \mathrm{CO}_{2}$ emissions by technology in the 2030 scenarios.

Unlike the Base Newlines scenario, electricity trading in the Hydro Newlines scenario relative to the Hydro scenario reduces $\mathrm{CO}_{2}$ emission from high-cost plants (diesel and heavy fuel) by $52 \%\left(4 \mathrm{MtCO}_{2}\right)$, while emissions from low-cost plants (coal and gas) increase by $4 \%$ (1.8 $\mathrm{MtCO}_{2}$ ). Comparing the Solar scenario and the Solar Newlines scenario, electricity trading reduces emission from diesel and heavy fuel plants by $88 \%\left(5.1 \mathrm{MtCO}_{2}\right)$, while coal and gas plants emission increases by $1 \%\left(0.3 \mathrm{MtCO}_{2}\right)$.

\subsection{Economic impact of RES integration}

Cross-border electricity trading in the Base Newlines scenario increases total generation cost in the region by $\$ 314 \mathrm{M} /$ year, which is $7 \%$ higher than the total cost in the Base scenario. This increase in total system cost mainly comes from the use of high cost diesel and heavy fuel power plants for import when other technologies are operating at maximum levels. On the other hand, cross-border electricity trading in the Hydro Newlines and Solar Newlines scenarios results in savings of $\$ 706 \mathrm{M} /$ year and $\$ 1.1 \mathrm{~B} /$ year, which is equivalent to a $15 \%$ and $32 \%$ decrease from the Hydro and Solar scenarios respectively. These cost savings are because of lower operating cost from the additional hydro and solar PV plants that replace portions of gas, diesel and heavy fuel plants electricity generation. This implies that in the absence of sufficient generating capacity and the use of diesel and heavy fuel power plants by 10 out of 14 countries in the region, increased cross-border electricity trading between West African countries could result in an increase in total generation cost in the region. This increase in generation cost can be reduced with the integration of RES to increase the reserve capacity in each country. The total annual cost of electricity generation for each country in the six scenarios evaluated is presented in Table A.9. The estimated total capital cost for the additional $5 \mathrm{GW}$ hydro plants in the Hydro scenario and $38 \mathrm{GW}$ solar PV plants in the Solar scenario is \$12.5B and \$52B respectively.

The marginal cost of electricity generation in each country is the variable cost of producing one more MW of electricity, and is used to assume the hourly wholesale electricity prices in each country. The monthly average marginal cost of generation in the six scenarios is presented in Figure 7. It is observed that in the Base, Hydro, and Solar scenarios when interconnection is limited, countries with electricity generation mixes mostly based on diesel and heavy fuel plants have a higher marginal cost relative to countries with lower cost power plants. As expected, the hydro plants and solar PV integration in the Hydro and Solar scenarios decreases the average marginal cost of electricity generation in the country they were installed in, with the most significant changes in Liberia ( $\$ 145 / \mathrm{MWh}$ to $\$ 9 / \mathrm{MWh})$ and Mali $(\$ 126 / \mathrm{MWh}$ to 
$\$ 58 / \mathrm{MWh}$ ). Consequently, this decrease is expected to be reflected in the electricity prices to customers. The degree to which this will impact electricity prices will be dependent on several factors like the liberalisation of the country's national electricity sectors and the national policies in terms of support schemes for generation companies.

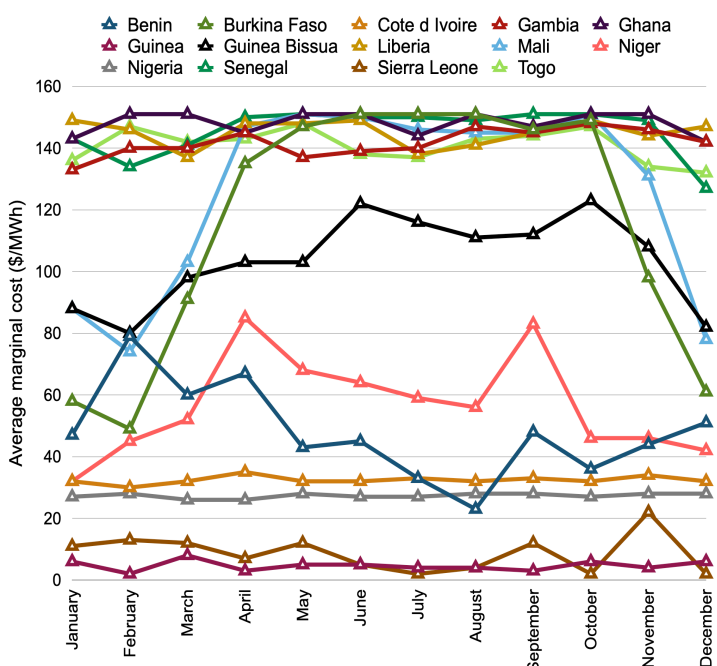

$\Delta$ Benin $\Delta$ Burkina Faso $\stackrel{\text { Base Scenario }}{\Delta \text { Coted lvoire } \Delta \text { Gambia } \Delta \text { Ghan }}$ $\Delta$ Guinea $\Delta$ Guinea Bissua $\Delta$ Liberia $\Delta$ Mali $\Delta$ Niger

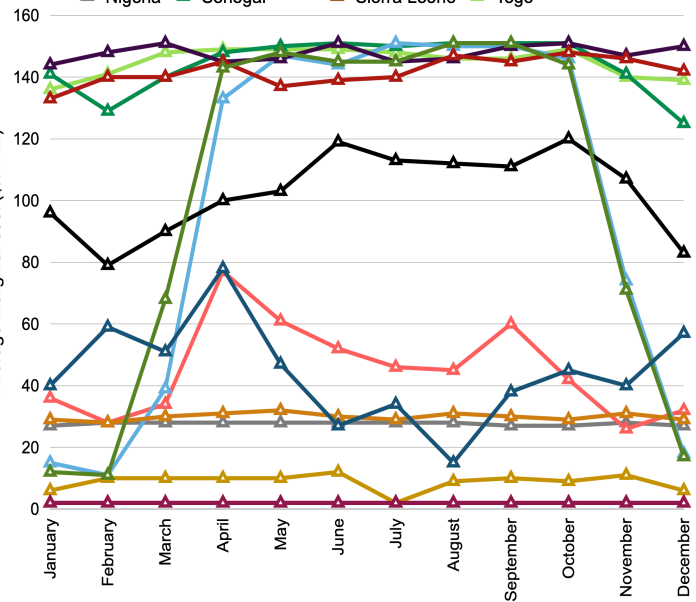

Hydro Scenario

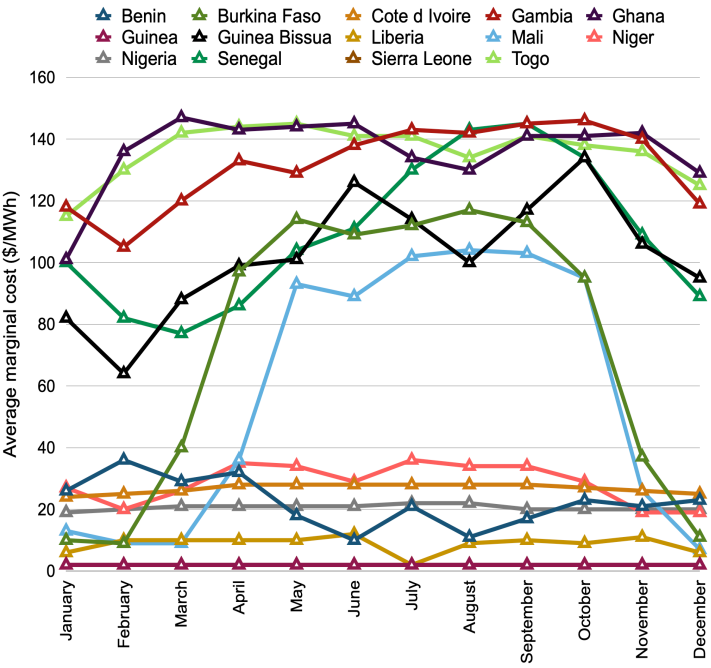

Solar Scenario
$\Delta$ Benin $\triangle$ Burkina Faso $\Delta$ Cote d lvoire $\Delta$ Gambia $\Delta$ Ghan

$\Delta$ Guinea $\Delta$ Guinea Bissua $\Delta$ Liberia $\triangleq$ Mali $\triangleq$ Niger

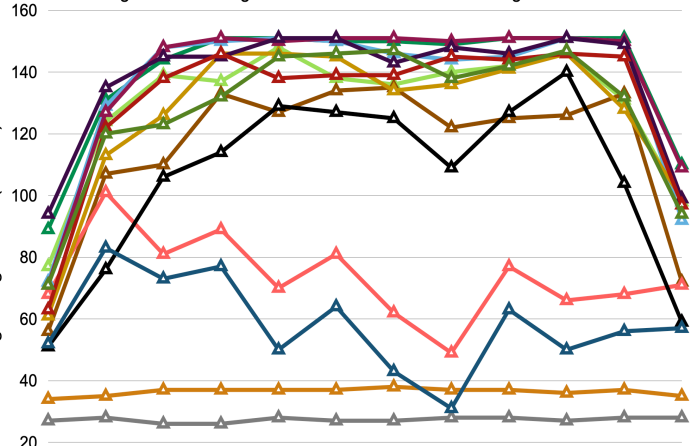

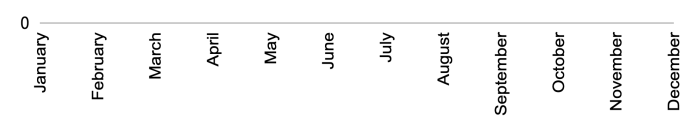

Base Newlines Scenario
$\Delta$ Benin $\Delta$ Burkina Faso $\Delta$ Cote d lvoire $\Delta$ Gambia $\Delta$ Ghana $\Delta$ Guinea $\Delta$ Guinea Bissua $\Delta$ Liberia $\Delta$ Mali $\Delta$ Niger $\Delta$ Nigeria $\Delta$ Senegal

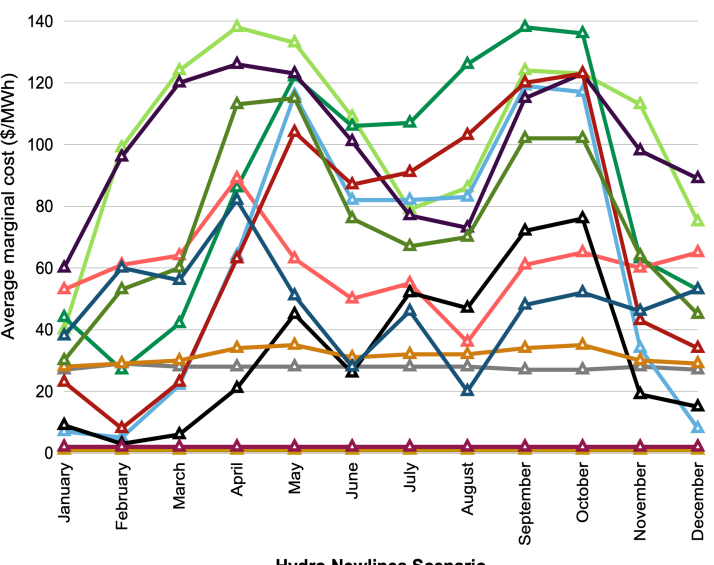

Hydro Newlines Scenario

$\Delta$ Benin $\Delta$ Burkina Faso $\Delta$ Cote d lvoire $\Delta$ Gambia $\Delta$ Ghana Guinea $\Delta$ Guinea Bissua $\Delta$ Liberia $\Delta$ Mali $\Delta$ Niger $\Delta$ Nigeria $\Delta$ Senegal $\quad \Delta$ Sierra Leone $\triangleq$ Togo

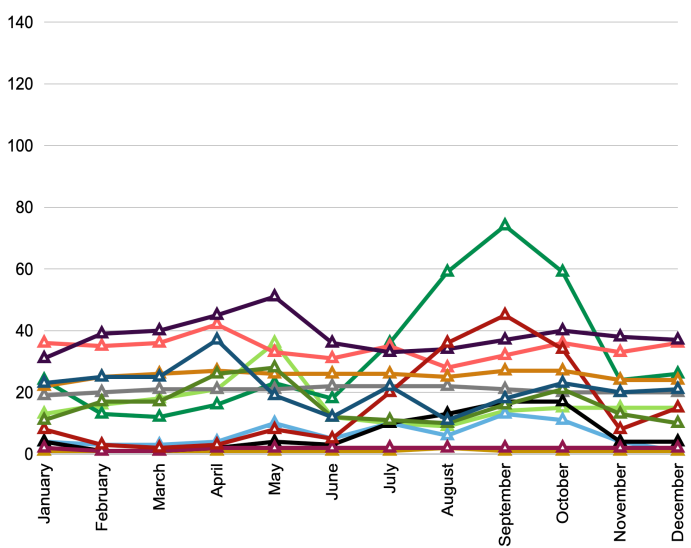

Solar Newlines Scenario

Figure 7. Monthly average marginal cost of electricity generation in the 2030 scenarios 
The Base Newlines and Hydro Newlines scenarios (Figure 7) where all 14 countries are interconnected, illustrates how increasing cross-border electricity trading could lead to a convergence of average marginal costs when there are insufficient generation capacities in some countries. The annual average marginal cost for the region in the Base Newlines scenario increases to $\$ 106 / \mathrm{MWh}$ from $\$ 89 / \mathrm{MWh}$ in the Base scenario. This is as a result of cross-border electricity trading in the Base Newlines scenario significantly increasing the marginal cost in Guinea and Sierra Leone, because these countries use their reserve diesel and heavy fuel plants to generate electricity for export. On the other hand, the annual average marginal cost for the region in the Hydro Newlines decreases to \$50/MWh from \$75/MWh in the Hydro scenario.

The average monthly marginal cost of both net importing and exporting countries reduces in the Solar Newlines scenario relative to its limited interconnection scenario (Solar), except for Niger. This is because the new interconnection to Burkina Faso leads to Niger increasing its diesel and coal generation to meet peak demand in Burkina Faso. The annual average marginal cost for the region in the Solar Newlines scenarios decreases to $\$ 17 / \mathrm{MWh}$ from $\$ 61 / \mathrm{MWh}$ in Solar scenarios. The countries that benefit the most from increased cross-border electricity trading in terms of reduced marginal cost, are the countries with low reserve margin that have substantial share of diesel and heavy fuel plants in its total capacity in each scenario. Nigeria's average marginal cost remains mostly constant because it only exports approximately $4 \%$ of the total electricity generated in the country.

\subsection{Cross-border electricity trade and utilization of interconnection capacities}

In 2016, with only nine out of fourteen countries interconnected, the total electricity traded in West Africa was $4 \mathrm{TWh}$, which accounted for approximately $9 \%$ of the total electricity generated in the region. The net exporters in 2016 were Cote d Ivoire, Mali and Nigeria, while the remaining six countries were net importers. The total regional electricity traded in the Base, Base Newlines, Hydro, Hydro Newlines, Solar and Solar Newlines scenarios in 2030 is 17 TWh, 65 TWh, 16.8 TWh, $68 \mathrm{TWh}, 16 \mathrm{TWh}, 67.7 \mathrm{TWh}$, accounting for 10\%, 35\%, 9\%, 36\%, $8 \%$ and $35 \%$ respectively of the total electricity generated in the region. The share of electricity generated in each country that is exported to other countries, and the share of electricity consumed in each country that is from imports is shown in Figure 8. In three of the scenarios, some countries depend on import to meet more than $50 \%$ of its electricity demand. Burkina Faso in the Base Newlines scenario, four countries (Burkina Faso, Gambia, Senegal and Togo) in Hydro Newlines scenario, and only Gambia in Solar Newlines scenario. The 2030 electricity export and import levels for each country in the six scenarios is presented in Table A.10.

The additional interconnections to neighboring countries could provide some countries an opportunity to increase its electricity import and reduce its electricity generation from the relatively high-cost power plants (diesel and heavy fuel). In the Base Newlines scenario, Liberia increases its import by $41 \%$, and its electricity generation from high-cost power plants is reduced by $6 \%$ in comparison to the Base scenario. Gambia's import is increased by $60 \%$ in the Hydro Newlines scenario, and its electricity generation from diesel plants is reduced by $9 \%$ in comparison to the Hydro scenario. In the Solar Newlines scenario, Gambia increases its import by $67 \%$, and its electricity generation from high-cost power plants is reduced by $47 \%$ in comparison to the Solar scenario.

In the Hydro Newlines scenario, the increase of low-cost hydro capacities in Cote d Ivoire, Guinea, Liberia and Sierra Leone results in increased electricity export to Burkina Faso, Ghana, Guinea Bissau, Mali, and Senegal. 


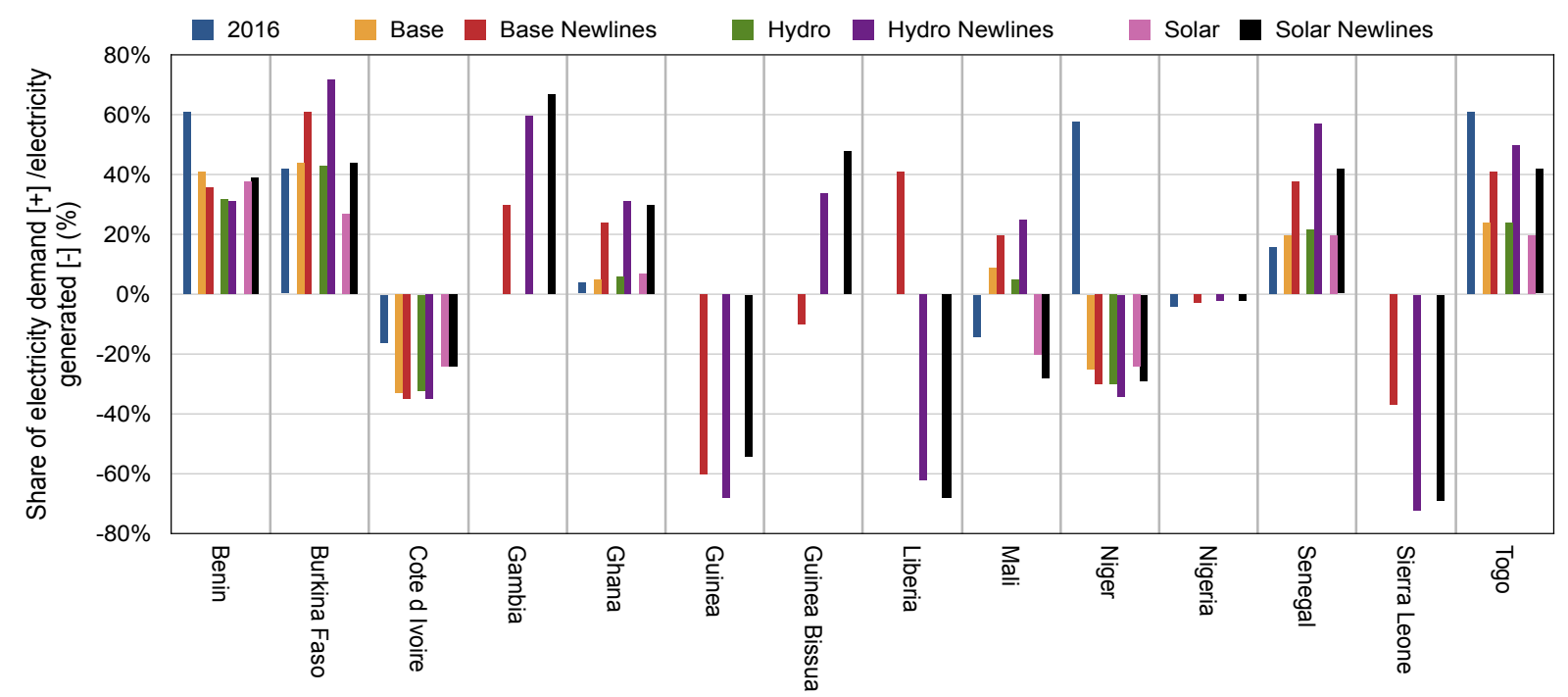

Figure 8. Electricity trading in 2016 and 2030 scenarios

In the Solar Newlines scenario, the integration of additional solar PV plants in Burkina Faso, Senegal, and Togo, results in these countries reducing their import by up to $28 \%, 15 \%$ and $8 \%$ respectively, while Mali becomes a net exporter. Benin, Gambia and Guinea Bissau are the only countries to increase their import in the Solar Newlines scenario, this is as a result of these countries importing low-cost electricity instead of utilizing its high cost diesel and heavy fuel power plant reserves.

Capacity utilization of the interconnection lines is the ratio of the power flow on the line to the maximum flow allowed on the line. Table 2 shows the annual capacity utilization of all 25 interconnection lines in the West African region for the six different scenarios. In the Base Newlines scenario, majority of the interconnection lines are under-utilized with only 11 out of the 25 lines utilized up to $50 \%$. This implies that the currently proposed interconnection capacities in the region can accommodate more cross-border electricity trading. Increased amounts of RES in the Hydro Newlines, and Solar Newlines scenarios increases the utilization level of more interconnections, with some lines fully utilized. The results indicate that additional hydro power plants in Cote d'Ivoire, Guinea and Liberia could lead to congestion in interconnection lines to Ghana, Guinea Bissau, Mali and Senegal.

\subsection{Sensitivity analysis}

We carried out a sensitivity analysis on the impact of lower electricity demand levels in 2030 and thus higher reserve margins, on cross-border electricity trading between West African countries in a fully interconnected West African grid. The ECOWAS energy targets [14] estimates $75 \%$ of the total population in each country will be connected to the grid by 2030 . For the sensitivity analysis, we assume a lower electricity access rate of $50 \%$ due to lower GDP growth and investment. Information on the peak demand and annual electricity consumption for each country in the low electricity demand scenario is presented in Table A.1. The regional annual electricity consumption in the low demand scenarios is $142 \mathrm{TWh} / \mathrm{year}$, while the demand used in the previous six scenarios analysed is $196 \mathrm{TWh} / y e a r$. In the three low demand scenarios when all fourteen countries are interconnected, the share of electricity traded with respect to electricity generated in region increases. With electricity trading in the low demand scenarios accounting for up to $48 \%$ of the total electricity generated in the region, on the other hand in the initial demand scenarios trading accounted for up to $36 \%$. Benin and Gambia 
significantly increase their imports from countries with low cost reserve power plants, and thus decrease their generation from diesel and heavy fuel power plants. Furthermore, it was observed that Guinea Bissua and Mali were also sensitive to lower demand levels, with Guinea Bissua changing from a net exporter to a net importer in the Base Newlines scenario, and vice versa for Mali in the Hydro Newlines scenario. This is due to Guinea Bissua reducing exports from its high-cost reserve plants and Mali having more hydro plants reserve margins that is used for exports.

Table 2: Capacity utilization on the interconnection lines in 2030 scenarios.

\begin{tabular}{|c|c|c|c|c|c|c|c|}
\hline Interconnection lines & Countries & Base & $\begin{array}{l}\text { Base } \\
\text { Newlines }\end{array}$ & Hydro & $\begin{array}{l}\text { Hydro } \\
\text { Newlines }\end{array}$ & Solar & $\begin{array}{l}\text { Solar } \\
\text { Newlines }\end{array}$ \\
\hline Abobo - Prestea & Cote d Ivoire - Ghana & $94 \%$ & $100 \%$ & $97 \%$ & $100 \%$ & $97 \%$ & $100 \%$ \\
\hline Abobo- Prestea $2 *$ & Cote d Ivoire - Ghana & - & $53 \%$ & - & $70 \%$ & - & $64 \%$ \\
\hline Akosombo - Lome & Ghana - Togo & $61 \%$ & $42 \%$ & $60 \%$ & $46 \%$ & $50 \%$ & $40 \%$ \\
\hline Bamako - Fomi* & Mali - Guinea & - & $61 \%$ & - & $100 \%$ & - & $75 \%$ \\
\hline Birkelane - Soma* & Senegal - Gambia & - & $34 \%$ & - & $69 \%$ & - & $47 \%$ \\
\hline Birnin kebbi - Niamey & Nigeria - Niger & $47 \%$ & $52 \%$ & $54 \%$ & $45 \%$ & $48 \%$ & $46 \%$ \\
\hline Birnin kebbi - Niamey $2 *$ & Nigeria - Niger & - & $16 \%$ & - & $14 \%$ & - & $14 \%$ \\
\hline Bobo Dioulasso - Sikasso* & Burkina Faso - Mali & - & $64 \%$ & - & $77 \%$ & - & $78 \%$ \\
\hline Bolgatanga - BoboDioulasso* & Ghana - Burkina Faso & - & $52 \%$ & - & $61 \%$ & - & $64 \%$ \\
\hline Bolgatanga - Ouagadougou* & Ghana - Burkina Faso & - & $52 \%$ & - & $61 \%$ & - & $64 \%$ \\
\hline Bumbuna - Linsan* & Sierra Leone -Guinea & - & $13 \%$ & - & $42 \%$ & - & $49 \%$ \\
\hline Ferkessedougou -BoboDioulasso & Cote d Ivoire - Burkina Faso & $83 \%$ & $64 \%$ & $83 \%$ & $84 \%$ & $66 \%$ & $60 \%$ \\
\hline Ferkessedougou -Sikasso & Cote d Ivoire - Mali & $82 \%$ & $46 \%$ & $81 \%$ & $53 \%$ & $53 \%$ & $53 \%$ \\
\hline Ikeja west - Sakete & Nigeria - Benin & $35 \%$ & $37 \%$ & $32 \%$ & $33 \%$ & $30 \%$ & $33 \%$ \\
\hline Kaolack - Linsan* & Senegal - Guinea & - & $75 \%$ & - & $100 \%$ & - & $78 \%$ \\
\hline Kastina - Maradi & Nigeria - Niger & $48 \%$ & $53 \%$ & $54 \%$ & $45 \%$ & $48 \%$ & $46 \%$ \\
\hline Man - Yekepa* & Cote d Ivoire - Liberia & - & $36 \%$ & - & $100 \%$ & - & $100 \%$ \\
\hline Manantali - Matam & Mali - Senegal & $81 \%$ & $37 \%$ & $88 \%$ & $42 \%$ & $83 \%$ & $50 \%$ \\
\hline Mansoa - Linsan* & Guinea Bissua - Guinea & - & $47 \%$ & - & $99 \%$ & - & $76 \%$ \\
\hline Monrovia - Bumbuna* & Liberia - Sierra Leone & - & $22 \%$ & - & $54 \%$ & - & $51 \%$ \\
\hline Niamey - Ouagadougou* & Niger - Burkina Faso & - & $75 \%$ & - & $65 \%$ & - & $61 \%$ \\
\hline Soma-Bissau* & Gambia - Guinea Bissua & - & $45 \%$ & - & $91 \%$ & - & $69 \%$ \\
\hline Volta - Lome* & Ghana - Togo & - & $16 \%$ & - & $17 \%$ & - & $15 \%$ \\
\hline Yekepa - Nzerekore* & Liberia - Guinea & - & $26 \%$ & - & $30 \%$ & - & $30 \%$ \\
\hline Zabori - Bembereke* & Niger - Togo & - & $12 \%$ & - & $12 \%$ & - & $14 \%$ \\
\hline
\end{tabular}

The second sensitivity analysis carried out is the impact of significant changes $(+30 \%,-30 \%)$ in gas, diesel and heavy fuel prices on cross-border electricity trading. It was observed that in the three scenarios where all the fourteen countries are interconnected, cross-border electricity trading is not sensitive to a $30 \%$ decrease in gas diesel and heavy fuel prices. However, when there is a $30 \%$ increase in these fuel prices in the Base Newlines scenario, all of the net importing countries increase their import levels, with Gambia and Liberia having significant increase of up to $27 \%$. This is as a result of these two countries having more than $45 \%$ of its installed capacity from both diesel and heavy plants in this scenario. On the other hand, in the Hydro Newlines and Solar Newlines scenario when there was significant increase in hydro and solar plant integration, a 30\% increase in these fuel prices has no noticeable impact on crossborder electricity trading. This implies that electricity trading in the region is only sensitive to increase in fuel prices in the Base Newlines scenario where there is a comparatively higher supply-demand gap in most countries.

\section{Conclusion}

The main aim of this study was to quantify the potential impact of increasing renewable energy sources and electricity interconnections between West Africa countries on: electricity generation, electricity demand, cross-border electricity trading, carbon emissions, and electricity generation cost in the region. ECOWAS and WAPP are eager to provide access to 
affordable electricity in all 14 West African countries, and thus improve economic growth in the region by creating an integrated regional electricity market. Results from the modelled scenarios in this study show that cross-border electricity trading is a feasible option to achieve affordable electricity in the region, if there is an increase in grid-connected hydro and solar power plants. The high integration of grid connected hydro and solar PV plants culminates in a 30\% decrease in total cost of electricity generation in the region, while an increase in crossborder electricity trading could reduce the cost up to $53 \%$. Integration of these renewable energy sources results in decreasing the marginal cost of electricity production, with an annual average decrease of $31 \%$. However, in two scenarios with increased renewable energy sources and interconnections, monthly average marginal cost in the region converges. This increase in marginal cost of net exporting countries highlights the potential setback of having insufficient generation capacities in several countries while increasing interconnections in the region. This leads to countries with high-cost fossil fuel reserve plants generating electricity for exports, in order to meet unserved demand in interconnected countries. In the scenario with the highest renewable energy sources integration and interconnections, the average monthly marginal cost of both net importing and exporting countries reduces, except for Niger. Our sensitivity analysis showed that a significant increase in diesel, heavy fuel and gas prices may result in Gambia and Liberia having to increase electricity import by up to $27 \%$. This is due to these two countries having more than $45 \%$ of their installed capacity from diesel and heavy fuel power plants. However, with additional hydro and solar PV plants despite an increase in fuel prices, these countries may not increase their electricity import by more than $2 \%$. This highlights the potential of renewable energy sources in providing electricity supply independence for each country in the region.

The current proposed expansion plan in the region will see an additional $2.5 \mathrm{GW}$ and $0.8 \mathrm{GW}$ of coal and diesel power plants respectively installed by 2030. The scenarios presented in our study show that investments in unexplored hydro and solar resources could achieve the aim of WAPP to reduce the supply-demand gap and electricity prices in the region. The results from this study indicate that increasing cross-border electricity trading could potentially reduce unserved demands by up to $46 \%$, when compared to the scenario where all the currently planned power plants are operational. On the other hand, it also increases electricity generation from heavy fuel, diesel, and gas plants by $16 \%, 8 \%$, and $5 \%$ respectively. Therefore, crossborder trading has the potential to increase overall $\mathrm{CO}_{2}$ emissions, total generation cost and marginal cost in the region, when there is insufficient generation capacity and high-cost fossil fuel reserve power plants in net importing and net exporting countries respectively. However, in the scenario where the ECOWAS renewable energy policy target is met, cross-border trading could potentially reduce generation from diesel and heavy fuel plants by up to $87 \%$, and consequently reduce overall $\mathrm{CO}_{2}$ emission by meeting demand with imports from hydro and solar PV plants. Presently, since there is no carbon tax in any of the West African countries to provide incentive for reducing $\mathrm{CO}_{2}$ emissions, increasing cross-border electricity trading is a possible option to achieving reduced levels of $\mathrm{CO}_{2}$ emissions. Furthermore, increasing the integration of solar PV and interconnection capacities could provide low-cost electricity during off-peak periods for the pumping operations of the PHES, which consequently results in an increase in generation from the PHES during peak periods.

Our study showed that majority of the currently planned interconnection capacities could be underutilized in 2030 given the current national and regional plans for new power plants. This highlights the opportunity for the proposed ECOWAS regional renewable energy policy targets to be used for exports to countries with high share of diesel and heavy fuel generation in its electricity mix. It is important to note that the results in our study are specific to the six 
scenarios and modelling assumptions presented. However, the results provide an understanding of role of RES and energy storage in meeting future electricity demand, and facilitating electricity trading in a fully interconnected electricity network in West Africa. Furthermore, this work is an important step in analysing the development of the regional electricity market in the WAPP. Interconnection capacities for cross-border electricity trading can be allocated using explicit and implicit auction methods. In the explicit auction approach, interconnection capacities are traded separately from electricity, while in implicit auction, available interconnection capacities between bidding countries are included during the bidding process, thus the wholesale price includes the cost of electricity and congestion. Our future work will include examining efficient interconnection routes between countries and analysing the impact of explicit and implicit allocation of interconnection capacities on individual countries.

\section{Acknowledgements}

The authors will like to thank Prof Neil Strachan of the UCL Energy Institute for his constructive comments on this paper. The authors will like to appreciate the WAPP Information and coordination Centre for the data they provided. The authors will like to thank the Petroleum Technology Development Fund Nigeria (PTDF) for funding this research. The views in this study are those of the authors and do not necessarily reflect the views of PTDF.

\section{Appendix A}

\section{A.1 Distribution of West African solar corridor road map targets}

The solar plants in Benin, Nigeria and Togo are proposed to include both solar PV and CSP plants, while the remaining 6 countries will only build new solar PV plants. We assume $10 \%$ of the solar plant target in these three countries will be the CSP plants. Yushchenko et al. [77] presents the technical potential and suitable sites for grid connected solar PV and CSP plants in West Africa using geographical information systems and multi-criteria decision methodologies. Based on resultant maps which are accessible here [74], we selected the best suitable sites for the solar PV and CSP which are at least $200 \mathrm{~m}$ apart and are within $1 \mathrm{~km}$ to the transmission grid. The solar targets in each country are equally split between the selected sites as shown in Figure A.1.

\section{A.2 Selection of potential pumped hydro plant sites}

The ECOWREX data file [74] of up to 500,00 rivers in West Africa is used in this study. The data includes information about the river's location, potential hydro power capacity, volume, area, slope, monthly water flow and elevation. We identified potential PHES sites by selecting existing unexploited reservoirs/lakes that have a close suitable site within $5 \mathrm{~km}$ that can function as a second reservoir [78] . The following constraints were applied to the first reservoir; minimum hydro power potential capacity of $100 \mathrm{MW}$, minimum volume of $1,000,000 \mathrm{~m}^{3}$, minimum head of $150 \mathrm{~m}$ and maximum distance of $20 \mathrm{~km}$ to an existing transmission grid. On the other hand, the second site should have a minimum area of $60,000 \mathrm{~m}^{2}$ and minimum slope of 10 degrees. Based on the aforementioned criteria, four potential PHES sites were identified in the region and are listed in Table A.5. 
Table A.1. Annual electricity consumption and peak demand for each West African country in 2030 six scenarios and low demand scenario.

\begin{tabular}{|llllll|}
\hline & 2030 six scenarios & & & \multicolumn{2}{l|}{$\begin{array}{l}\text { 2030 low demand } \\
\text { scenario }\end{array}$} \\
\cline { 1 - 2 } \cline { 5 - 6 } Country & Peak demand (MW) & Annual demand (GWh) & & Peak demand (MW) & Annual demand (GWh) \\
\hline Benin & 865 & 3510 & 646 & 2619 \\
Burkina Faso & 1452 & 5220 & 995 & 3574 \\
Cote d Ivoire & 2976 & 14980 & 952 & 1984 & 9987 \\
Gambia & 268 & 29275 & 268 & 881 \\
Ghana & 5770 & 3424 & 4006 & 20320 \\
Guinea & 608 & 165 & 405 & 2282 \\
Guinea Bissua & 37 & 892 & 29 & 128 \\
Liberia & 190 & 4830 & 126 & 595 \\
Mali & 1236 & 3690 & 824 & 3220 \\
Niger & 1103 & 115466 & 788 & 2636 \\
Nigeria & 24481 & 8615 & 18270 & 86175 \\
Senegal & 2200 & 862 & 2184 & 7500 \\
Sierra Leone & 166 & 3850 & 110 & 574 \\
Togo & 710 & & 508 & 2749 \\
\hline
\end{tabular}

Table A.2: Operating parameter assumptions for the different types of power plants.

\begin{tabular}{|c|c|c|c|c|c|c|}
\hline Power Plant & $\begin{array}{l}\text { Capacity } \\
\text { factor }(\%)\end{array}$ & $\begin{array}{l}\text { Carbon emission } \\
\left(\mathrm{kgCO}_{2} / \mathrm{MWh}\right)\end{array}$ & $\begin{array}{l}\text { Heat Rate } \\
\text { (GJ/MWh) }\end{array}$ & $\begin{array}{l}\text { Ramp Rate (\% } \\
\text { full load/min) }\end{array}$ & $\begin{array}{l}\text { Minimum } \\
\text { Stable level (\% } \\
\text { full load) }\end{array}$ & $\begin{array}{l}\text { Outage Rate } \\
(\%)\end{array}$ \\
\hline Coal & 85 & 870 & 9.5 & 4 & 20 & 15 \\
\hline Diesel & 80 & 700 & 9 & 7 & 10 & 17 \\
\hline Heavy fuel & 85 & 675 & 9 & 7 & 10 & 17 \\
\hline Gas & 85 & 400 & 7.5 & 6 & 15 & 15 \\
\hline Biomass & 60 & 0 & 9.6 & 6 & 25 & 15 \\
\hline Hydro & - & 0 & - & 20 & - & 6 \\
\hline Pumped Hydro & - & 0 & - & 25 & - & 6 \\
\hline Solar PV & - & 0 & - & - & - & 5 \\
\hline Solar CSP & - & - & - & 8 & - & 5 \\
\hline Wind & - & 0 & - & - & - & 5 \\
\hline
\end{tabular}

Table A.3. Projected economic parameters for the different types of power plants.

\begin{tabular}{|llllll|}
\hline Power Plant & $\begin{array}{l}\text { Domestic fuel price } \\
(\$ / \mathrm{GJ})\end{array}$ & $\begin{array}{l}\text { Imported fuel price } \\
(\$ / \mathrm{GJ})\end{array}$ & $\begin{array}{l}\text { Variable O\&M } \\
\text { cost }(\$ / \mathrm{MWh})\end{array}$ & $\begin{array}{l}\text { Capital cost } \\
(\$ / \mathrm{kW})\end{array}$ & $\begin{array}{l}\text { Fixed O\&M cost } \\
(\$ / \mathrm{kW} / \text { year })\end{array}$ \\
\hline Coal & 2.1 & 0 & 3.2 & 1300 & 45 \\
Diesel & 0 & 15.7 & 10.1 & 1500 & 70 \\
Heavy Fuel & 0 & 14 & 7.1 & 1500 & 70 \\
Gas & 3.6 & 9.4 & 2 & 700 & 25 \\
Biomass & 3.6 & 0 & 4.2 & 2100 & 75 \\
Hydro & 0 & 0 & 0 & 2100 & 55 \\
Pumped Hydro & 0 & 0 & 0 & 2000 & 200 \\
Solar PV & 0 & 0 & 0 & 1400 & 22 \\
Solar CSP & 0 & 0 & 4 & 3800 & 150 \\
Wind & 0 & 0 & 0 & 1760 & 44 \\
\hline
\end{tabular}


Table A.4. Existing and proposed interconnections between West African countries

\begin{tabular}{|c|c|c|c|c|c|c|}
\hline Interconnection lines & Countries & $\begin{array}{l}\text { Maximum } \\
\text { Flow } \\
\text { Capacity } \\
\text { (MW) }\end{array}$ & Status & $\begin{array}{l}\text { Voltage Level } \\
(\mathrm{kV})\end{array}$ & $\begin{array}{l}\text { Length } \\
(\mathrm{km})\end{array}$ & Loss $(\%)$ \\
\hline Abobo - Prestea & Cote d Ivoire - Ghana & 320 & Existing & 225 & 210 & 14 \\
\hline Abobo- Prestea 2 & Cote d Ivoire - Ghana & 650 & Proposed & 330 & 210 & 14 \\
\hline Akosombo - Lome & Ghana - Togo & 250 & Existing & 161 & 130 & 20 \\
\hline Bamako - Fomi & Mali - Guinea & 320 & Proposed & 225 & 300 & 9 \\
\hline Birkelane - Soma & Senegal - Gambia & 340 & Proposed & 225 & 90 & 13 \\
\hline Birnin kebbi - Niamey & Nigeria - Niger & 200 & Existing & 132 & 255 & 16 \\
\hline Birnin kebbi - Niamey 2 & Nigeria - Niger & 650 & Proposed & 330 & 255 & 16 \\
\hline Bobo Dioulasso - Sikasso & Burkina Faso - Mali & 310 & Proposed & 225 & 160 & 15 \\
\hline Bolgatanga - BoboDioulasso & Ghana - Burkina Faso & 330 & Proposed & 225 & 380 & 20 \\
\hline Bolgatanga - Ouagadougou & Ghana - Burkina Faso & 330 & Proposed & 225 & 200 & 20 \\
\hline Bumbuna - Linsan & Sierra Leone -Guinea & 330 & Proposed & 225 & 320 & 15 \\
\hline $\begin{array}{l}\text { Ferkessedougou - } \\
\text { BoboDioulasso }\end{array}$ & $\begin{array}{l}\text { Cote d Ivoire - Burkina } \\
\text { Faso }\end{array}$ & 320 & Existing & 225 & 205 & 14 \\
\hline Ferkessedougou -Sikasso & Cote d Ivoire - Mali & 320 & Existing & 225 & 210 & 14 \\
\hline Ikeja west - Sakete & Nigeria - Benin & 680 & Existing & 330 & 70 & 16 \\
\hline Kaolack - Linsan & Senegal - Guinea & 280 & Proposed & 225 & 455 & 13 \\
\hline Kastina - Maradi & Nigeria - Niger & 200 & Existing & 132 & 140 & 16 \\
\hline Man - Yekepa & Cote d Ivoire - Liberia & 340 & Proposed & 225 & 152 & 14 \\
\hline Manantali - Matam & Mali - Senegal & 250 & Existing & 225 & 450 & 9 \\
\hline Mansoa - Linsan* & Guinea Bissua - Guinea & 310 & Proposed & 225 & 300 & 15 \\
\hline Monrovia - Bumbuna & Liberia - Sierra Leone & 300 & Proposed & 225 & 330 & 15 \\
\hline Niamey - Ouagadougou & Niger - Burkina Faso & 640 & Proposed & 330 & 420 & 18 \\
\hline Soma-Bissau & Gambia - Guinea Bissua & 330 & Proposed & 225 & 180 & 15 \\
\hline Volta - Lome & Ghana - Togo & 655 & Proposed & 330 & 100 & 20 \\
\hline Yekepa - Nzerekore & Liberia - Guinea & 340 & Proposed & 225 & 49 & 15 \\
\hline Zabori - Bembereke & Niger - Togo & 650 & Proposed & 330 & 312 & 18 \\
\hline
\end{tabular}

Table A.5. Operating parameter assumptions for the pumped hydro power plants.

\begin{tabular}{|l|l|l|l|l|}
\hline Country & River & $\begin{array}{l}\text { Annual mean } \\
\text { discharge (m3/s) }\end{array}$ & $\begin{array}{l}\text { Generation Capacity } \\
(\mathrm{MW})\end{array}$ & $\begin{array}{l}\text { Maximum } \\
\text { storage capacity } \\
(\mathrm{MWh})\end{array}$ \\
\hline Ghana & Volta & 1172 & 523 & 4190 \\
\hline Nigeria & Kaduna & 320 & 263 & 2103 \\
\hline Nigeria & Donga & 97 & 130 & 1048 \\
\hline Sierra Leone & Sewa & 227 & 128 & 1026 \\
\hline
\end{tabular}

Table A.6. Installed capacities in each country for the different scenarios.

\begin{tabular}{|c|c|c|c|c|c|c|c|c|c|c|c|c|}
\hline \multirow[t]{2}{*}{ Country } & & \multicolumn{8}{|c|}{ Base Scenario (MW) } & \multicolumn{2}{|c|}{$\begin{array}{l}\text { Hydro Scenario } \\
(M W)\end{array}$} & \multirow{2}{*}{ 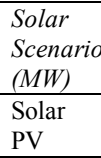 } \\
\hline & Gas & Diesel & $\begin{array}{l}\text { Heavy } \\
\text { Fuel }\end{array}$ & Coal & Hydro & $\begin{array}{l}\text { Solar } \\
\text { PV }\end{array}$ & $\begin{array}{l}\text { Solar } \\
\text { CSP }\end{array}$ & Wind & Biomass & Hydro & $\begin{array}{l}\text { Pumped } \\
\text { Hydro }\end{array}$ & \\
\hline Benin & 550 & 93 & 0 & 0 & 0 & 132 & 15 & 0 & 5 & 160 & 0 & 660 \\
\hline Burkina Faso & 0 & 243 & 0 & 0 & 29 & 368 & 0 & 0 & 0 & 101 & 0 & 1840 \\
\hline Cote d Ivoire & 1908 & 0 & 0 & 700 & 1257 & 438 & 0 & 0 & 71 & 1834 & 0 & 2190 \\
\hline Gambia & 0 & 6 & 90 & 0 & 0 & 30 & 0 & 5 & 0 & 0 & 0 & 150 \\
\hline Ghana & 1443 & 946 & 0 & 0 & 1580 & 678 & 0 & 225 & 0 & 1891 & 524 & 3390 \\
\hline Guinea & 0 & 179 & 90 & 0 & 1802 & 0 & 0 & 0 & 0 & 3814 & 0 & 0 \\
\hline $\begin{array}{l}\text { Guinea } \\
\text { Bissau }\end{array}$ & 0 & 21 & 0 & 0 & 20 & 0 & 0 & 0 & 0 & 20 & 0 & 0 \\
\hline Liberia & 0 & 23 & 28 & 0 & 64 & 0 & 0 & 0 & 0 & 947 & 0 & 0 \\
\hline Mali & 0 & 147 & 41 & 0 & 455 & 643 & 0 & 1 & 0 & 605 & 0 & 3215 \\
\hline Niger & 0 & 144 & 0 & 636 & 130 & 152 & 0 & 0 & 0 & 279 & 0 & 760 \\
\hline Nigeria & 12150 & 0 & 0 & 1200 & 6348 & 6491 & 600 & 10 & 0 & 6348 & 394 & 32456 \\
\hline Senegal & 0 & 305 & 186 & 125 & 128 & 378 & 0 & 225 & 15 & 128 & 0 & 1890 \\
\hline Sierra Leone & 0 & 64 & 0 & 0 & 238 & 5 & 0 & 0 & 15 & 827 & 128 & 25 \\
\hline Togo & 0 & 31 & 100 & 0 & 214 & 137 & 15 & 25 & 0 & 264 & 0 & 685 \\
\hline
\end{tabular}


Table A.7. Additional grid-connected solar and hydro power plant capacities.

\begin{tabular}{|lllll|}
\hline & $\begin{array}{l}\text { West African } \\
\text { solar corridor } \\
\text { capacities [76] }\end{array}$ & & $\begin{array}{l}\text { Hydro power } \\
\text { plants potential } \\
{[13]}\end{array}$ \\
\cline { 1 - 3 } Country & Solar PV (MW) & $\begin{array}{l}\text { Solar CSP } \\
\text { (MW) }\end{array}$ & $\begin{array}{l}\text { Additional } \\
\text { capacities (MW) }\end{array}$ \\
\hline Benin & 132 & 15 & 160 \\
Burkina Faso & 204 & 0 & 72 \\
Cote d Ivoire & 423 & 0 & 577 \\
Gambia & 0 & 0 & 0 \\
Ghana & 501 & 0 & 311 \\
Guinea & 0 & 0 & 2012 \\
Guinea Bissua & 0 & 0 & 0 \\
Liberia & 0 & 0 & 883 \\
Mali & 530 & 0 & 150 \\
Niger & 152 & 0 & 149 \\
Nigeria & 6230 & 600 & 0 \\
Senegal & 260 & 0 & 0 \\
Sierra Leone & 0 & 0 & 590 \\
Togo & 132 & 15 & 50 \\
\hline
\end{tabular}

Table A.8. Pumped hydro generation in the different scenarios.

\begin{tabular}{|llll|}
\hline Scenario & $\begin{array}{l}\text { Installed Solar PV } \\
\text { capacity (GW) }\end{array}$ & $\begin{array}{l}\text { Interconnection } \\
\text { capacity }(\mathrm{GW})\end{array}$ & $\begin{array}{l}\text { Generation from } \\
\text { pumped hydro } \\
\text { plants (GWh/year) }\end{array}$ \\
\hline Hydro & 9.5 & 2.5 & 526 \\
Hydro Newlines & 9.5 & 9.6 & 710 \\
Solar & 47 & 2.5 & 897 \\
Solar Newlines & 47 & 9.6 & 1380 \\
\hline
\end{tabular}

Table A.9. Total cost of electricity generation in the 2030 scenarios (Million \$)

\begin{tabular}{|c|c|c|c|c|c|c|c|c|c|}
\hline Country & Base & $\begin{array}{l}\text { Base } \\
\text { Newlines }\end{array}$ & $\begin{array}{l}\text { Change in } \\
\text { cost }\end{array}$ & Hydro & $\begin{array}{l}\text { Hydro } \\
\text { Newlines }\end{array}$ & $\begin{array}{l}\text { Change in } \\
\text { cost }\end{array}$ & Solar & $\begin{array}{l}\text { Solar } \\
\text { Newlines }\end{array}$ & $\begin{array}{l}\text { Change in } \\
\text { cost }\end{array}$ \\
\hline Benin & 124 & 147 & 23 & 107 & 117 & 10 & 51 & 49 & -2 \\
\hline Burkina Faso & 149 & 170 & 21 & 134 & 76 & -58 & 92 & 15 & -77 \\
\hline Cote D'Ivoire & 438 & 473 & 35 & 394 & 423 & 29 & 254 & 254 & 0 \\
\hline Gambia & 71 & 68 & -3 & 69 & 35 & -34 & 60 & 7 & -53 \\
\hline Ghana & 1099 & 996 & -103 & 1094 & 632 & -462 & 933 & 287 & -646 \\
\hline Guinea & 9 & 203 & 194 & 7 & 21 & 14 & 7 & 15 & 8 \\
\hline Guinea Bissua & 12 & 14 & 2 & 12 & 4 & -8 & 12 & 1 & -11 \\
\hline Liberia & 42 & 33 & -9 & 3 & 5 & 2 & 3 & 6 & 3 \\
\hline Mali & 122 & 135 & 13 & 101 & 40 & -61 & 56 & 8 & -48 \\
\hline Niger & 118 & 142 & 24 & 108 & 127 & 19 & 74 & 86 & 12 \\
\hline Nigeria & 2065 & 2155 & 90 & 2090 & 2178 & 88 & 1409 & 1460 & 51 \\
\hline Senegal & 384 & 375 & -9 & 372 & 156 & -216 & 251 & 40 & -211 \\
\hline Sierra Leone & 5 & 51 & 46 & 2 & 6 & 4 & 2 & 6 & 4 \\
\hline Togo & 104 & 94 & -10 & 105 & 72 & -33 & 97 & 12 & -85 \\
\hline Total & 4742 & 5056 & 314 & 4598 & 3892 & -706 & 3301 & 2246 & -1055 \\
\hline
\end{tabular}


Table A.10. Electricity import and export in West African countries in the six scenarios analysed.

\begin{tabular}{|c|c|c|c|c|c|c|c|c|c|c|c|c|}
\hline & \multicolumn{2}{|c|}{$\begin{array}{l}\text { Base Scenario } \\
(\mathrm{GWh})\end{array}$} & \multicolumn{2}{|c|}{$\begin{array}{l}\text { Base Newlines } \\
\text { Scenario (GWh) }\end{array}$} & \multicolumn{2}{|c|}{$\begin{array}{l}\text { Hydro Scenario } \\
\text { (GWh) }\end{array}$} & \multicolumn{2}{|c|}{$\begin{array}{l}\text { Hydro Newlines } \\
\text { Scenario (GWh) }\end{array}$} & \multicolumn{2}{|c|}{$\begin{array}{l}\text { Solar Scenario } \\
(\mathrm{GWh})\end{array}$} & \multicolumn{2}{|c|}{$\begin{array}{l}\text { Solar Newlines } \\
\text { Scenario (GWh) }\end{array}$} \\
\hline Countries & Export & Import & Export & Import & Export & Import & Export & Import & Export & Import & Export & Import \\
\hline Benin & 652 & 2079 & 3393 & 4657 & 773 & 1886 & 3397 & 4465 & 441 & 1767 & 3425 & 4805 \\
\hline $\begin{array}{l}\text { Burkina } \\
\text { Faso }\end{array}$ & 35 & 2326 & 5583 & 8787 & 43 & 2306 & 5341 & 9083 & 444 & 1849 & 6045 & 8317 \\
\hline $\begin{array}{l}\text { Cote d } \\
\text { Ivoire }\end{array}$ & 7214 & 280 & 11088 & 3199 & 7272 & 215 & 11988 & 4026 & 6034 & 1395 & 10245 & 5590 \\
\hline Gambia & 0 & 0 & 2302 & 2586 & 0 & 0 & 2079 & 2647 & 0 & 0 & 1821 & 2459 \\
\hline Ghana & 1428 & 3033 & 4770 & 11815 & 1317 & 3078 & 4293 & 13311 & 1124 & 3049 & 4303 & 13150 \\
\hline Guinea & 0 & 0 & 7972 & 2958 & 0 & 0 & 9691 & 2505 & 0 & 0 & 7953 & 3916 \\
\hline $\begin{array}{l}\text { Guinea } \\
\text { Bissua }\end{array}$ & 0 & 0 & 2581 & 2564 & 0 & 0 & 2647 & 2702 & 0 & 0 & 2420 & 2498 \\
\hline Liberia & 0 & 0 & 2809 & 3170 & 0 & 0 & 4152 & 2695 & 0 & 0 & 4417 & 2516 \\
\hline Mali & 1907 & 2355 & 3711 & 4694 & 2063 & 2289 & 3771 & 4953 & 2735 & 1577 & 5390 & 3477 \\
\hline Niger & 2136 & 923 & 8844 & 7339 & 2284 & 764 & 8911 & 7061 & 2049 & 894 & 8749 & 7263 \\
\hline Nigeria & 3001 & 2787 & 7509 & 4456 & 2650 & 3057 & 6942 & 5145 & 2660 & 2489 & 7283 & 4994 \\
\hline Senegal & 80 & 1763 & 1331 & 4563 & 35 & 1928 & 497 & 5417 & 111 & 1812 & 1040 & 4643 \\
\hline Sierra Leone & 0 & 0 & 2114 & 1632 & 0 & 0 & 3162 & 937 & 0 & 0 & 3253 & 1098 \\
\hline Togo & 420 & 1327 & 1196 & 2781 & 366 & 1281 & 1230 & 3155 & 330 & 1097 & 1342 & 2959 \\
\hline
\end{tabular}

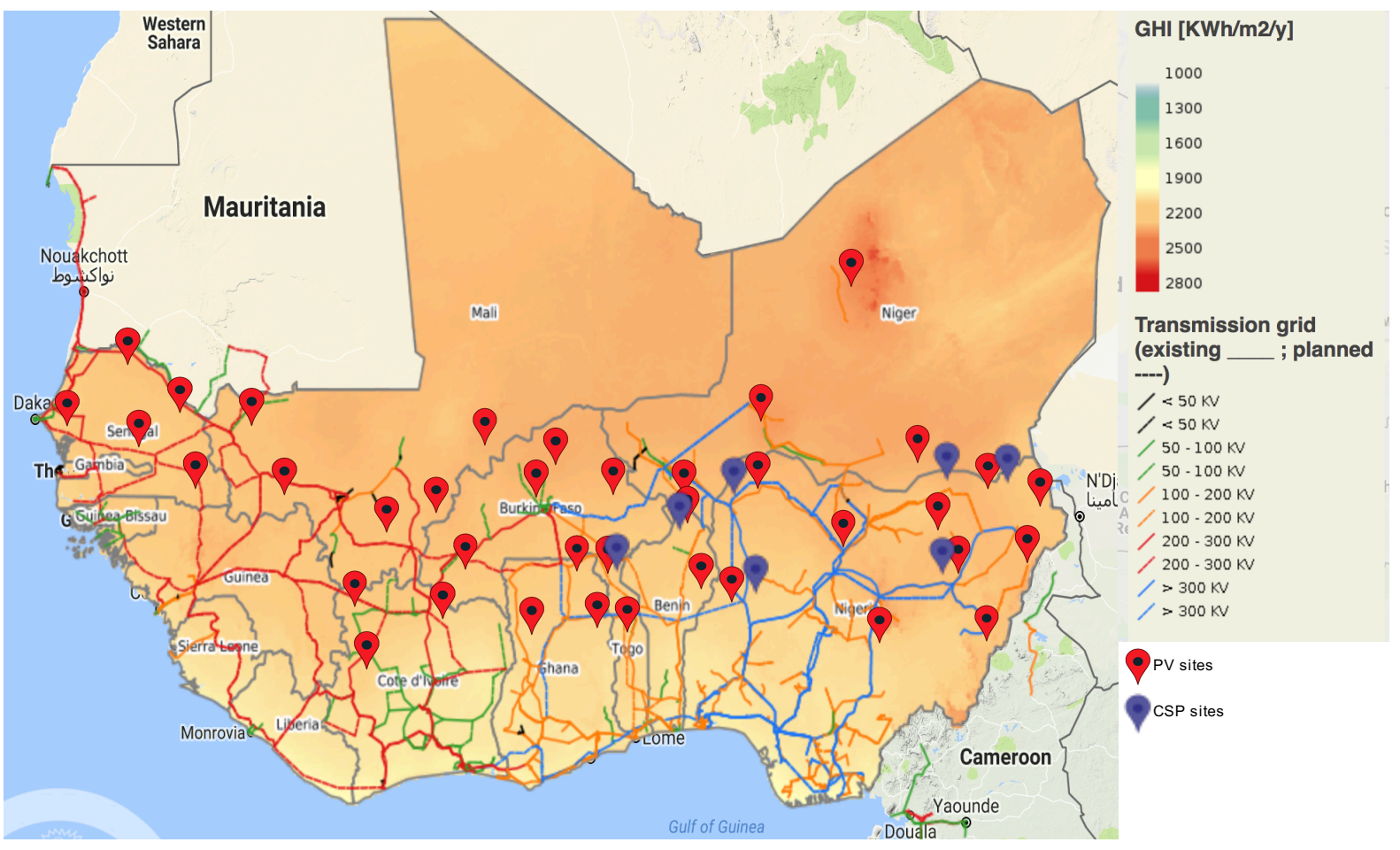

Figure A.1. Selected Solar PV and CSP power plant sites. Adapted from [74].

\section{References}

[1] IEA. Energy access database 2017. http://www.iea.org/energyaccess/database/ (accessed October 12, 2017).

[2] IRENA. Africa's Renewable Future: The path to Sustainable growth. vol. 60. Abu 
Dhabi, United Arab Emirates: 2013. doi:10.1016/j.worlddev.2014.03.016.

[3] ECOWAS. Decision A/Dec.5/12/99 Relating to the Establishment of the West African Power Pool 1999. http://www.ecowapp.org/sites/default/files/decision_a-dec.5-1299_establishment_of_wapp.pdf (accessed November 15, 2016).

[4] UNECA. Assessment of Power Pooling Arrangements in Africa. United Nations; 2003.

[5] WEC. Regional Energy Integration in Africa. United Kingdom: World Energy Council; 2005.

[6] Oseni MO, Pollitt MG. The promotion of regional integration of electricity markets: Lessons for developing countries. Energy Policy 2016;88:628-38. doi:10.1016/j.enpol.2015.09.007.

[7] West African Power Pool. 2016 - 2019 WAPP Business Plan 2015. http://www.ecowapp.org/sites/default/files/2015-2019_business_plan.pdf (accessed March 15, 2016).

[8] WEC. The Potential for Regionally Integrated Energy Development in Africa: a Discussion Document. United Kingdom: World Energy Council; 2003.

[9] ECOWAS. Directive C/DIR.1/06/13 On the Organisation of the Regional Electricity Market 2013. http://erera.arrec.org/en/2013/06/21/seventieth-ordinary-session-of-thecouncil-of-ministers-of-ecowas/ (accessed November 15, 2016).

[10] Masami K, Trimble C. Making Power Affordable for Africa and Viable for Its Utilities. Washington, DC, United States: The World Bank; 2016. doi:https://doi.org/10.1596/25091.

[11] ERERA. Approval of the Regional Maket Rules for the West African Power Pool 2015. http://icc.ecowapp.org/sites/default/files/Regional market rules_signed.pdf (accessed November 15, 2016).

[12] ERERA. ERERA' s Strategic Plan and activity programme 2016 - 20202016. https://erera.arrec.org/wp-content/uploads/2016/08/ERERA-s-Strategic-Plan-andActivity-Program-2016-2020.pdf (accessed May 5, 2016).

[13] West African Power Pool. Update of the ECOWAS Revised Master Plan for the Generation and Transmission of Electrical Energy: Final Report Volume 1: Study Data 2011. http://www.ecowapp.org/sites/default/files/mp_wapp_volume_1.pdf (accessed March 15, 2016).

[14] ECREEE. ECOWAS Renewable Energy Policy 2015. http://www.ecreee.org/sites/default/files/documents/ecowas_renewable_energy_policy .pdf (accessed March 5, 2016).

[15] ECREEE. Outcomes of the Dakar Sustainable Energy Forum | ECREEE 2017. http://www.ecreee.org/news/outcomes-dakar-sustainable-energy-forum (accessed February 6, 2018).

[16] Newbery D, Strbac G, Pudjianto D, Noel P, Fisher L. Benefits of an integrated European energy market. Amsterdam: Booz \& Company; 2013.

[17] Jacottet A. Cross-border electricity interconnections for a well-functioning EU Internal Electricity Market 2012.

[18] Benasla M, Allaoui T, Brahami M, Denaï M, Sood VK. HVDC links between North Africa and Europe: Impacts and benefits on the dynamic performance of the European system. Renew Sustain Energy Rev 2018;82:3981-91. doi:10.1016/j.rser.2017.10.075.

[19] Pollitt MG. The European Single Market in Electricity : An Economic Assessment. Rev Ind Organ 2019;55:63-87. doi:10.1007/s11151-019-09682-w.

[20] Zickfeld F, Wieland A, Blohmke J, Sohm M, Yousef A. Desert Power 2050:Perspectives on a Sustainable Power System for EUMENA. Munich: Dii GmbH; 2012. 
[21] Ochoa C, Van Ackere A. Does size matter? Simulating electricity market coupling between Colombia and Ecuador. Renew Sustain Energy Rev 2015;50:1108-24. doi:10.1016/j.rser.2015.05.054.

[22] Timilsina GR, Toman M. Potential gains from expanding regional electricity trade in South Asia. Energy Econ 2016;60:6-14. doi:10.1016/j.eneco.2016.08.023.

[23] Ouriachi A, Spataru C. Integrating regional electricity markets towards a single European market. 2015 12th Int. Conf. Eur. Energy Mark., IEEE; 2015, p. 1-5. doi:10.1109/EEM.2015.7216603.

[24] Finon D, Romano E. Electricity market integration: Redistribution effect versus resource reallocation. Energy Policy 2009;37:2977-85. doi:10.1016/j.enpol.2009.03.045.

[25] Spiecker S, Vogel P, Weber C. Evaluating interconnector investments in the north European electricity system considering fluctuating wind power penetration. Energy Econ 2013;37:114-27. doi:10.1016/j.eneco.2013.01.012.

[26] Otsuki T, Mohd Isa AB, Samuelson RD. Electric power grid interconnections in Northeast Asia: A quantitative analysis of opportunities and challenges. Energy Policy 2016;89:311-29. doi:10.1016/j.enpol.2015.11.021.

[27] Cleary B, Duffy A, Bach B, Vitina A, O'Connor A, Conlon M. Estimating the electricity prices, generation costs and $\mathrm{CO} 2$ emissions of large scale wind energy exports from Ireland to Great Britain. Energy Policy 2016;91:38-48. doi:10.1016/j.enpol.2015.12.036.

[28] Horst Keppler J, Phan S, Le Pen Y. The Impacts of Variable Renewable Production and Market Coupling on the Convergence of French and German Electricity Prices. Energy J 2016;37. doi:10.5547/01956574.37.3.jkep.

[29] Schaber K, Steinke F, Mühlich P, Hamacher T. Parametric study of variable renewable energy integration in Europe: Advantages and costs of transmission grid extensions. Energy Policy 2012;42:498-508. doi:10.1016/j.enpol.2011.12.016.

[30] Brancucci C, Brinkman G, Hodge B-M. The impact of wind power on electricity prices. Renew Energy 2016;94:474-87. doi:10.1016/j.renene.2016.03.053.

[31] Stich J, Mannhart M, Zipperle T, Massier T, Huber M, Hamacher T. Modelling a LowCarbon Power System for Indonesia, Malaysia and Singapore. 33rd IEW Int. Energy Work., 2014, p. 1-11.

[32] Giesbertz P, Mulder M. Economics of Interconnection : the Case of the Northwest European Electricity Market. Int Assoc Energy Econ 2008:17-21.

[33] Malaguzzi Valeri L. Welfare and competition effects of electricity interconnection between Ireland and Great Britain. Energy Policy 2009;37:4679-88. doi:10.1016/j.enpol.2009.06.020.

[34] Cebulla F, Naegler T, Pohl M. Electrical energy storage in highly renewable European energy systems: Capacity requirements, spatial distribution, and storage dispatch. J Energy Storage 2017;14:211-23. doi:10.1016/j.est.2017.10.004.

[35] Brouwer AS, van den Broek M, Zappa W, Turkenburg WC, Faaij A. Least-cost options for integrating intermittent renewables in low-carbon power systems. Appl Energy 2016;161:48-74. doi:10.1016/j.apenergy.2015.09.090.

[36] Grünewald P, Cockerill T, Contestabile M, Pearson P. The role of large scale storage in a GB low carbon energy future: Issues and policy challenges. Energy Policy 2011;39:4807-15. doi:10.1016/j.enpol.2011.06.040.

[37] Mileva A, Johnston J, Nelson JH, Kammen DM. Power system balancing for deep decarbonization of the electricity sector. Appl Energy 2016;162:1001-9. doi:10.1016/j.apenergy.2015.10.180.

[38] de Sisternes FJ, Jenkins JD, Botterud A. The value of energy storage in decarbonizing 
the electricity sector. Appl Energy 2016;175:368-79.

doi:10.1016/j.apenergy.2016.05.014.

[39] Safaei H, Keith DW. How much bulk energy storage is needed to decarbonize electricity? Energy Environ Sci 2015;8:3409-17. doi:10.1039/C5EE01452B.

[40] Pudjianto D, Aunedi M, Djapic P, Strbac G. Whole-systems assessment of the value of energy storage in low-carbon electricity systems. IEEE Trans Smart Grid 2014;5:1098-109. doi:10.1109/TSG.2013.2282039.

[41] Denholm P, Hand M. Grid flexibility and storage required to achieve very high penetration of variable renewable electricity. Energy Policy 2011;39:1817-30. doi:10.1016/j.enpol.2011.01.019.

[42] Connolly D, Lund H, Mathiesen B V., Pican E, Leahy M. The technical and economic implications of integrating fluctuating renewable energy using energy storage. Renew Energy 2012;43:47-60. doi:10.1016/j.renene.2011.11.003.

[43] Brancucci C, Vandenbergh M, de Vries L, Alecu C, Purvins A, Fulli G, et al. Mediumterm demand for European cross-border electricity transmission capacity. Energy Policy 2013;61:207-22. doi:10.1016/j.enpol.2013.05.073.

[44] Brancucci C, De Vries L. Are cross-border electricity transmission and pumped hydro storage complementary technologies? Int Conf Eur Energy Mark EEM 2013. doi:10.1109/EEM.2013.6607370.

[45] Lueken R, Apt J. The effects of bulk electricity storage on the PJM market. Energy Syst 2014;5:677-704. doi:10.1007/s12667-014-0123-7.

[46] Solomon AA, Kammen DM, Callaway D. The role of large-scale energy storage design and dispatch in the power grid: A study of very high grid penetration of variable renewable resources. Appl Energy 2014;134:75-89. doi:10.1016/j.apenergy.2014.07.095.

[47] Krishnan V, Das T. Optimal allocation of energy storage in a co-optimized electricity market: Benefits assessment and deriving indicators for economic storage ventures. Energy 2015;81:175-88. doi:10.1016/j.energy.2014.12.016.

[48] Das T, Krishnan V, McCalley JD. Assessing the benefits and economics of bulk energy storage technologies in the power grid. Appl Energy 2015;139:104-18. doi:10.1016/j.apenergy.2014.11.017.

[49] Go RS, Munoz FD, Watson JP. Assessing the economic value of co-optimized gridscale energy storage investments in supporting high renewable portfolio standards. Appl Energy 2016;183:902-13. doi:10.1016/j.apenergy.2016.08.134.

[50] Nyamdash B, Denny E, O’Malley M. The viability of balancing wind generation with large scale energy storage. Energy Policy 2010;38:7200-8. doi:10.1016/j.enpol.2010.07.050.

[51] Foley AM, Leahy PG, Li K, McKeogh EJ, Morrison AP. A long-term analysis of pumped hydro storage to firm wind power. Appl Energy 2015;137:638-48. doi:10.1016/j.apenergy.2014.07.020.

[52] Tuohy A, O’Malley M. Pumped storage in systems with very high wind penetration. Energy Policy 2011;39:1965-74. doi:10.1016/j.enpol.2011.01.026.

[53] Fürsch M, Hagspiel S, Jägemann C, Nagl S, Lindenberger D, Tröster E. The role of grid extensions in a cost-efficient transformation of the European electricity system until 2050. Appl Energy 2013;104:642-52. doi:10.1016/j.apenergy.2012.11.050.

[54] Huber M, Roger A, Hamacher T. Optimizing long-term investments for a sustainable development of the ASEAN power system. Energy 2015;88:180-93. doi:10.1016/j.energy.2015.04.065.

[55] Bogdanov D, Breyer C. North-East Asian Super Grid for 100\% renewable energy supply: Optimal mix of energy technologies for electricity, gas and heat supply 
options. Energy Convers Manag 2016;112:176-90.

doi:10.1016/j.enconman.2016.01.019.

[56] Sparrow FT, Masters WA, Bowen BH. Electricity Trade and Capacity Expansion Options in West Africa Summary. United States: Purdue University; 2002.

[57] Gnansounou E, Bayem H, Bednyagin D, Dong J. Strategies for regional integration of electricity supply in West Africa. Energy Policy 2007;35:4142-53.

doi:10.1016/j.enpol.2007.02.023.

[58] Adeoye O, Spataru C. Sustainable development of the West African Power Pool: Increasing solar energy integration and regional electricity trade. Energy Sustain Dev 2018;45:124-34. doi:https://doi.org/10.1016/j.esd.2018.05.007.

[59] IRENA. West African Power Pool: Planning and Prospects for Renewable Energy. Abu Dhabi: International Renewable Energy Agency (IRENA); 2013.

[60] The World Bank. Getting Electricity 2019. http://www.doingbusiness.org/data/exploretopics/getting-electricity (accessed May 2, 2017).

[61] PLEXOS. PLEXOS Integrated Energy Model: Simulation software for energy market analysis 2010. https://energyexemplar.com/software/plexos-desktop-edition/ (accessed February 21, 2016).

[62] Adeoye O, Spataru C. Modelling and forecasting hourly and annual electricity demand in West African countries. Manuscr Submitt Publ 2018.

[63] ECREEE. Power Plants 2017. http://www.ecowrex.org/resources/energy_generators (accessed May 15, 2017).

[64] WAPP- ICC. Monthly Operations Report. Benin: West African Power Pool Information and Coordination Centre; 2016.

[65] IEA. Power generation assumptions in the New Policies and 450 Scenarios in the World Energy Outlook 20162016. http://www.iea.org/media/weowebsite/energymodel/WEO_2016_PG_Assumptions_N PSand450_Scenario.xlsb (accessed December 3, 2016).

[66] International Energy Agency. The Power of Transformation: Wind, Sun and the Economics of Flexible Power Systems. France: International Energy Agency; 2014.

[67] IEA. CO2 emissions from fuel combustion 2017. http://www.oecdilibrary.org/energy/co2-emissions-from-fuel-combustion-2017_co2 fuel-2017-en (accessed November 8, 2017).

[68] International Energy Agency. World Energy Outlook 2016. France: International Energy Agency; 2016.

[69] Pfenninger S, Staffell I. Renewables.ninja 2017. https://www.renewables.ninja (accessed February 4, 2017).

[70] Huld T, Müller R, Gambardella A. A new solar radiation database for estimating PV performance in Europe and Africa. Sol Energy 2012;86:1803-15. doi:10.1016/j.solener.2012.03.006.

[71] National Renewable Energy Laboratory. System Advisor Model Version 2017.9.5 (SAM 2017.9.5) 2017. https://sam.nrel.gov/content/downloads. (accessed March 3, 2018).

[72] World Bank. World Bank Open Data 2019. http://data.worldbank.org (accessed March 1, 2018).

[73] International Energy Agency. Statistics 2018. https://www.iea.org/classicstats/statisticssearch/ (accessed March 4, 2018).

[74] ECOWREX. Map Viewer 2017. http://www.ecowrex.org/page/maps (accessed January 12, 2017).

[75] IRENA. Electricity storage and renewables: Costs and markets to 2030. Abu Dhabi: 
IRENA; 2017. doi:ISBN 978-92-9260-038-9 (PDF).

[76] ECREEE. West African Solar Corridor Road Map West African Solar Corridor Road Map : 2017:1-34. http://esef2017.org/wp-

content/uploads/2017/10/05_Day3_Session1B_Solar-Corridor-Road-Map_JAmissahArthur.pdf (accessed February 15, 2018).

[77] Yushchenko A, de Bono A, Chatenoux B, Kumar Patel M, Ray N. GIS-based assessment of photovoltaic (PV) and concentrated solar power (CSP) generation potential in West Africa. Renew Sustain Energy Rev 2016;81:2088-103. doi:10.1016/j.rser.2017.06.021.

[78] Arántegui RL, Evangelos Tzimas, Bocin-Dumitriu A, Zubaryeva A. SETIS expert workshop on the assessment of the potential of pumped hydropower storage 1 2012:29. doi:10.2790/53924. 